\title{
Article \\ Effect of Neuroprotective Magnesium Sulfate Treatment on Brain Transcription Response to Hypoxia Ischemia in Neonate Mice
}

\author{
Bérénice Le Dieu-Lugon ${ }^{1}$, Nicolas Dupré ${ }^{1}$, Céline Derambure ${ }^{2}$, François Janin ${ }^{1}$, Bruno J. Gonzalez ${ }^{1}$, \\ Stéphane Marret ${ }^{1,3} \mathbb{D}$, Arnaud Arabo ${ }^{4}$ and Philippe Leroux ${ }^{1, * \mathbb{D}}$
}

1 INSERM-UMR1245, Team 4, Epigenetics and Physiopathology of Neurodevelopmental Brain Lesions, Faculté de Médecine et de Pharmacie, Normandie Université Rouen, 22 Boulevard Gambetta, 76183 Rouen, France; berenice.le.dieu.lugon@orange.fr (B.L.D.-L.); dupre_nicolas@hotmail.fr (N.D.); francois.janin@univ-rouen.fr (F.J.); bruno.gonzales@univ-rouen.fr (B.J.G.); stephane.marret@chu-rouen.fr (S.M.)

2 INSERM-UMR1245, Team 1, Genetic Predisposition to Cancer, Faculté de Médecine et de Pharmacie, Normandie Université, 22 Boulevard Gambetta, 76183 Rouen, France; celine.derambure1@univ-rouen.fr

3 Neonatal Pediatrics, Intensive Care Unit and Neuropediatrics, Rouen University Hospital, 1 Rue de Germont, 76031 Rouen, France

4 CURIB, CURIB, Faculté des Sciences et Techniques, Normandie Université, Place Emile Blondel, 76130 Mont-Saint Aignan, France; arnaud.arabo@univ-rouen.fr

* Correspondence: philippe.leroux@univ-rouen.fr; Tel.: +33-2-35-14-8339

check for updates

Citation: Le Dieu-Lugon, B.; Dupré, N.; Derambure, C.; Janin, F.; Gonzalez, B.J.; Marret, S.; Arabo, A.; Leroux, P. Effect of Neuroprotective Magnesium Sulfate Treatment on Brain Transcription Response to Hypoxia Ischemia in Neonate Mice. Int. J. Mol. Sci. 2021, 22, 4253. https://doi.org/10.3390/ijms22084253

Academic Editor: Olivier Baud

Received: 2 April 2021

Accepted: 15 April 2021

Published: 20 April 2021

Publisher's Note: MDPI stays neutral with regard to jurisdictional claims in published maps and institutional affiliations.

Copyright: (c) 2021 by the authors. Licensee MDPI, Basel, Switzerland. This article is an open access article distributed under the terms and conditions of the Creative Commons Attribution (CC BY) license (https:/ / creativecommons.org/licenses/by/ $4.0 /)$.

\begin{abstract}
MgSO}_{4}$ is widely used in the prevention of preterm neurological disabilities but its modes of action remain poorly established. We used a co-hybridization approach using the transcriptome in 5-day old mice treated with a single dose of $\mathrm{MgSO}_{4}(600 \mathrm{mg} / \mathrm{kg})$, and/or exposed to hypoxiaischemia (HI). The transcription of hundreds of genes was altered in all the groups. $\mathrm{MgSO}_{4}$ mainly produced repressions culminating $6 \mathrm{~h}$ after injection. Bio-statistical analysis revealed the repression of synaptogenesis and axonal development. The putative targets of $\mathrm{MgSO}_{4}$ were $\mathrm{Mnk} 1$ and Frm1. A behavioral study of adults did not detect lasting effects of neonatal $\mathrm{MgSO}_{4}$ and precluded NMDA-receptor-mediated side effects. The effects of $\mathrm{MgSO}_{4}$ plus $\mathrm{HI}$ exceeded the sum of the effects of separate treatments. $\mathrm{MgSO}_{4}$ prior to $\mathrm{HI}$ reduced inflammation and the innate immune response probably as a result of cytokine inhibition ( $\mathrm{Ccl} 2$, Ifng, interleukins). Conversely, $\mathrm{MgSO}_{4}$ had little effect on $\mathrm{HI}$-induced transcription by RNA-polymerase II. De novo $\mathrm{MgSO}_{4}$ - $\mathrm{HI}$ affected mitochondrial function through the repression of genes of oxidative phosphorylation and many NAD-dehydrogenases. It also likely reduced protein translation by the repression of many ribosomal proteins, essentially located in synapses. All these effects appeared under the putative regulatory $\mathrm{MgSO}_{4}$ induction of the mTORC2 Rictor coding gene. Lasting effects through Sirt1 and Frm1 could account for this epigenetic footprint.
\end{abstract}

Keywords: neonate brain; hypoxia-ischemia; magnesium; transcriptome; neuroprotection; preterm; mouse

\section{Introduction}

Magnesium appears to be a potent tool for the prevention of cerebral palsy and resulting disabilities when administered as $\mathrm{MgSO}_{4}$ to women in danger of preterm delivery before 33 completed weeks of gestation (GWs) [1-4]. Historically, $\mathrm{MgSO}_{4}$ used as a tocolytic did not prove to have efficiency in retarding delivery, but retrospectively it has shown neuroprotection effects at low doses $[5,6]$. The $\mathrm{Mg}^{2+}$ ion has innumerable biological targets e.g., as co-factor in nucleic acid biology, protein synthesis, enzymatic systems, or proteinprotein interactions [7]. Its putative effects resulting in fetal neuroprotection are therefore very numerous, and its actual modes of action remain elusive. Given at neuroprotective (low) doses, $\mathrm{MgSO}_{4}$ has no deleterious side effects, which is a requirement for prophylactic 
treatment. However, owing to its large spectrum of putative effects, it appears necessary to strengthen the evidences of its harmlessness at neuroprotection doses, since high doses of $\mathrm{MgSO}_{4}$ have adverse effects at the cellular and whole-organism levels [8,9].

Pediatricians have detected diverse effects of prenatal $\mathrm{MgSO}_{4}$ in newborn presentation and behavior. Reports on cardiorespiratory function were somewhat controversial, showing no effect or depressant effect of antenatal magnesium [10,11]. It reduces heart rate but stabilizes blood pressure and reduces cerebral blood flow [10,12]. Overall, prenatal $\mathrm{MgSO}_{4}$ was shown to decrease the need to resort to intubation in very preterm births [13]. Finally, although $\mathrm{MgSO}_{4}$ supply has not been assessed as protective against bronchopulmonary dysplasia, hypomagnesemia was described as a risk factor [14].

Magnesium is mainly restrained in intracellular stores and circulating levels after bolus injection rapidly decrease due to near saturation of renal reabsorption pumps in physiological magnesemia conditions [15]. Antenatal magnesemia is high in the preterm and bolus $\mathrm{MgSO}_{4}$ resulted in a peak observed at delivery followed by a moderate hypermagnesemia during the first 3 days of life in very preterm infants exposed in utero [16,17]. In neonatal mice, the clearance of $\mathrm{Mg}^{2+}$ appeared even faster since no hyper-magnesemia remained $12 \mathrm{~h}$ after a $600-\mathrm{mg} / \mathrm{kg}$ bolus injection [18]. Thus, the presence of $\mathrm{MgSO}_{4}$ in the mother and fetus organisms after a low bolus administration is fleeting at the blood level, whereas lasting neuroprotection is expected and in fact observed in the subsequent hours and days $[15,19]$. It is possible that intracellular stores are rapidly sequestrated, although this requires active and saturable mechanisms. One may therefore consider the possibility that transient $\mathrm{Mg}^{2+}$ elevation initiates some processes that predispose the fetus against prospective noxious experiences, such as preterm birth and related consequences, somewhat as may proceed a pre-conditioning. Indeed, in animal studies, $\mathrm{Mg}^{2+}$ supplementation prevents maternal inflammation and offspring cerebral injuries [20-22].

It is likely that prenatal $\mathrm{Mg}^{2+}$ supplementation exerts neuroprotection via systemic and central effects. It has been suggested that direct effects at the fetal brain level occur through calcium antagonism and/or glutamate N-methyl- $D$-aspartate type glutamate receptor (NMDA) blockade [23]. Inflammation in the mother or consecutive hypoxia-ischemia is a major trigger of neonatal brain lesions and magnesium exerts anti-inflammatory activity in human or animal neonates [24,25]. $\mathrm{MgSO}_{4}$ pretreatment provided neuroprotection in the Rice and Vannucci experimental paradigm modeling hypoxia-ischemia (HI), and in the excitotoxic model of ibotenic acid injection [26,27]. In these models, the effects of $\mathrm{MgSO}_{4}$ do not account for maternal-mediated effects, suggesting direct effects in the neonate brain and improved delayed behavior [18,28]. In the 5 day-old mouse brain, HI provoked an early onset of coordinated gene inductions (repressions) $3 \mathrm{~h}$ to $12 \mathrm{~h}$ after insult, affecting transcription regulation at the RNA-polymerase-II complex, inflammation, cell death, and angiogenesis. In parallel, convergent gene repression affected many genes encoding for cholesterol metabolism enzymes and synaptic actors [29]. The causal factors of long-term deleterious consequences among these regulations are likely to be explored in the field of inflammation as well as its interaction with development [30-32].

Magnesium may affect a plethora of factors and interferes with $\mathrm{HI}[7,33,34]$. In light of our previous description of the strong effects of $\mathrm{HI}$ on the transcription pattern in P5 mice, the Rice and Vannucci model appeared to be a simple approach for an overview of mechanisms recruited in sole treatment with $\mathrm{MgSO}_{4}$, and of its modulation of HIeffects [29]. Neonatal mice at 5 days post-birth (P5) are usually considered a suitable model to explore brain development and injuries of human preterm born between 28 and 34 GW $[35,36]$. A further demonstration that the insult sensitivity of P5 and P10 mouse brains accurately mimicked preterm neonates and term infant brains was obtained through magnetic resonance imaging and histology after HI using the Rice and Vannucci model. In fact, P5 mice only showed white matter hypersignal and microglial activation. Moreover, age-dependent memory or social behavior defects were observed in adults $[28,37]$.

The period of special white matter vulnerability is the recommended therapeutic window of $\mathrm{MgSO}_{4}$ use (before $33 \mathrm{GW}$ ) for preterm prophylactic neuroprotection [38,39]. 
This study had dual goals-(i) the description of the proper effects of $\mathrm{MgSO}_{4}$ single bolus injection at P5 in mice, investigated at the transcription level in short delays and at the behavior level in grown-up mice, (ii) the identification of the $\mathrm{MgSO}_{4}$ interference with $\mathrm{HI}$ induced transcription effects and with spontaneous developmental transcription evolution.

\section{Results}

Transcriptome analyses were performed on the basis of three independent experiments. Experiment 1 compared the effects of single $\mathrm{MgSO}_{4}$ injection to phosphate buffered saline (PBS) injection, Experiment 2 compared the effects of $\mathrm{MgSO}_{4}$ or PBS injection prior to $\mathrm{HI}$, and Experiment 3 compared the effects of $\mathrm{HI}$ compared to control mice (Figure 1). The comparison of the 3 experiments was performed using the combination of two-color and one-color analyses of hybridization data detailed in Section 4.3 (Figure 2).

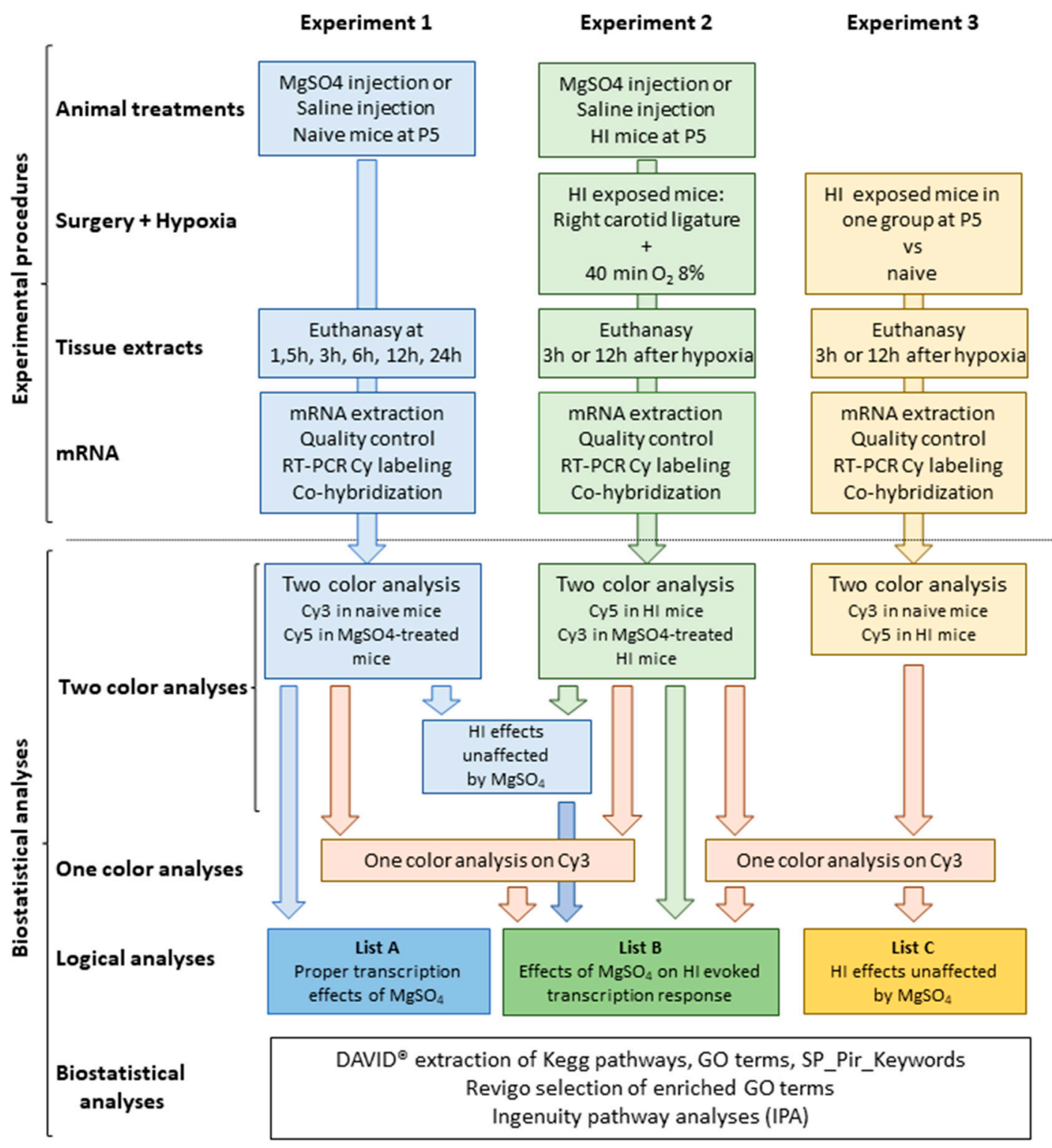

Figure 1. Experimental schedule. GO, Gene Ontology; HI, hypoxia-ischemia; P5, five days post-birth. 


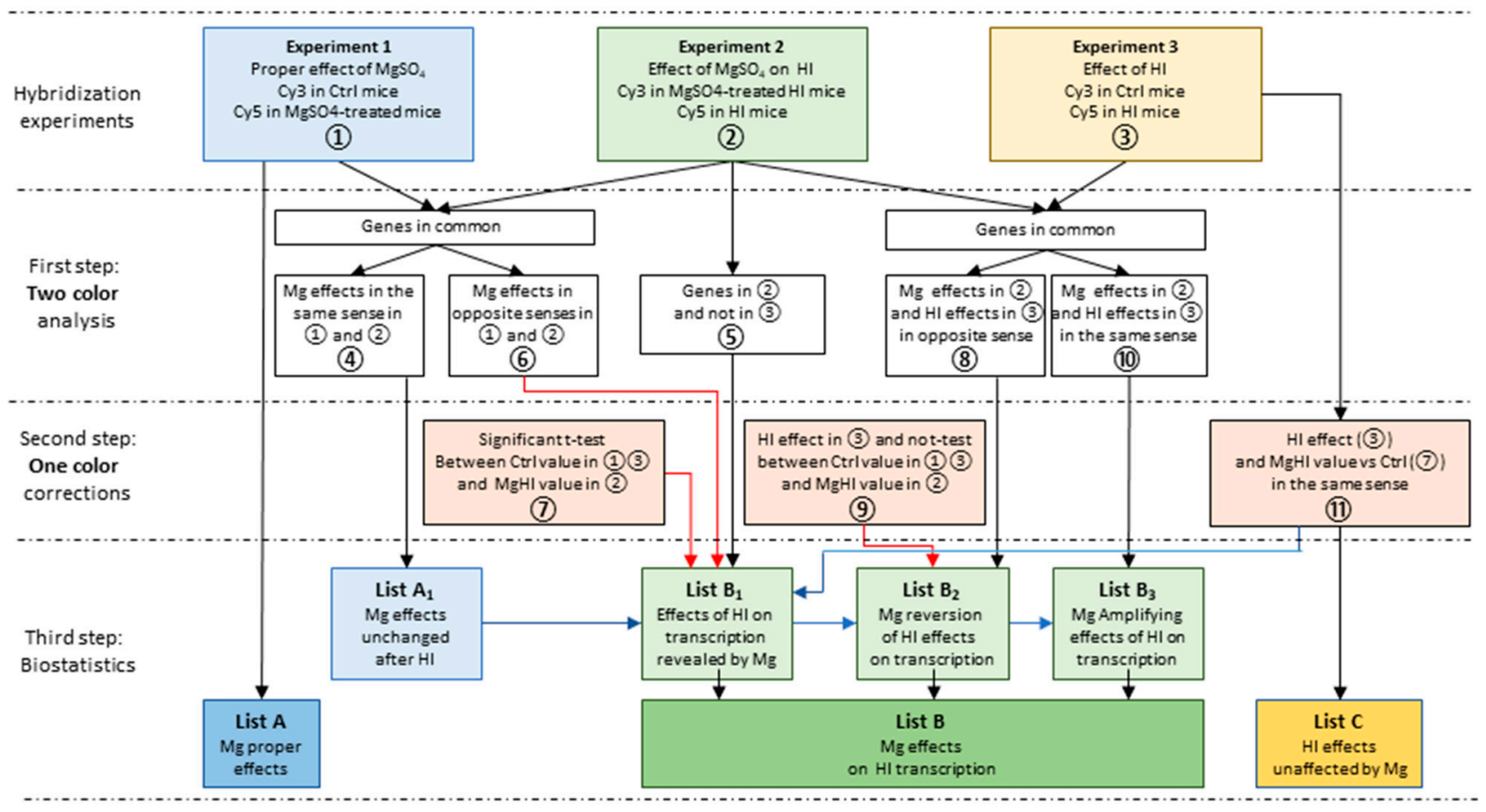

Figure 2. Detailed procedure of extraction of List A of proper effects of $\mathrm{MgSO}_{4}$ treatment, and List B collecting the different $\mathrm{MgSO}_{4}$ modulation of $\mathrm{HI}$ response to $\mathrm{HI}$ in $\mathrm{P} 5$ brain. All three experiments were analyzed independently (first step analyses in two-color co-hybridization experiments), providing lists of genes noted (1), (2), and (3). The genes detected in experiment 1 provided the List A of proper effects of $\mathrm{MgSO}_{4}$ single injection, to be submitted to pathway and gene ontology analyses. Coincident observations in (1) and (2) were extracted and split into two sub-series (4) and (6)). List B constitutes the effects of $\mathrm{MgSO}_{4}$ seen only in the $\mathrm{HI}$ context (List $\mathrm{B}_{1}$ ), $\mathrm{MgSO}_{4}$ reversion of $\mathrm{HI}$ effects (List $\mathrm{B}_{2}$ ), and $\mathrm{MgSO}_{4}$ amplification of $\mathrm{HI}$ effects (List $\mathrm{B}_{3}$ ), combining two-color and one-color analyses. The subseries of List $\mathrm{A}$ (4) — containing genes showing induction after $\mathrm{MgSO}_{4}$ injection in both control (1) and $\mathrm{HI}$-exposed (2) animals regrouping the genes affected by $\mathrm{MgSO}_{4}$ that were unchanged after $\mathrm{HI}$-was subtracted from List B. List C contains genes affected by $\mathrm{HI}$ in control as well as in $\mathrm{MgSO}_{4}$-pretreated mice. Black and Red arrows indicate two-color and one color insertions; blue arrows indicate subtractions in destination boxes.

\subsection{Effects of Single-Injection $\mathrm{MgSO}_{4}$ on Transcription}

A total of 1411 genes exhibited significant alteration of expression, at least at one time point from $90 \mathrm{~min}$ to $24 \mathrm{~h}$ after injection. Two-fold more repressions $(n=973)$ than inductions $(n=447)$ were recorded. Nine genes appeared in the induction and repression lists; with seven at the $6 \mathrm{~h}$ time point, revealed by separate probes, suggesting alternative splicing (Atp1a3, Aut2, Celf4, Kalrn, Psd3, Tenm4, Tln2), and two exhibiting successive opposite variation (Dmtn, Septin3) (Table S1A). The time course study revealed a wave of transcription inductions and repressions peaking after $6 \mathrm{~h}$ and including 1322 genes (93.7\% of the total list in $24 \mathrm{~h}$ ) (Figure 3A). The median fold change (FC) amplitude was significantly lower for inductions $(1.68 ; \mathrm{Q} 1=1.64-\mathrm{Q} 3=1.80)$ than for repression $(-1.82$; $\mathrm{Q} 1=-2.02-\mathrm{Q} 3=-1.65 ; p<0.0001$; according to the Mann-Whitney test) (Figure S1A). 

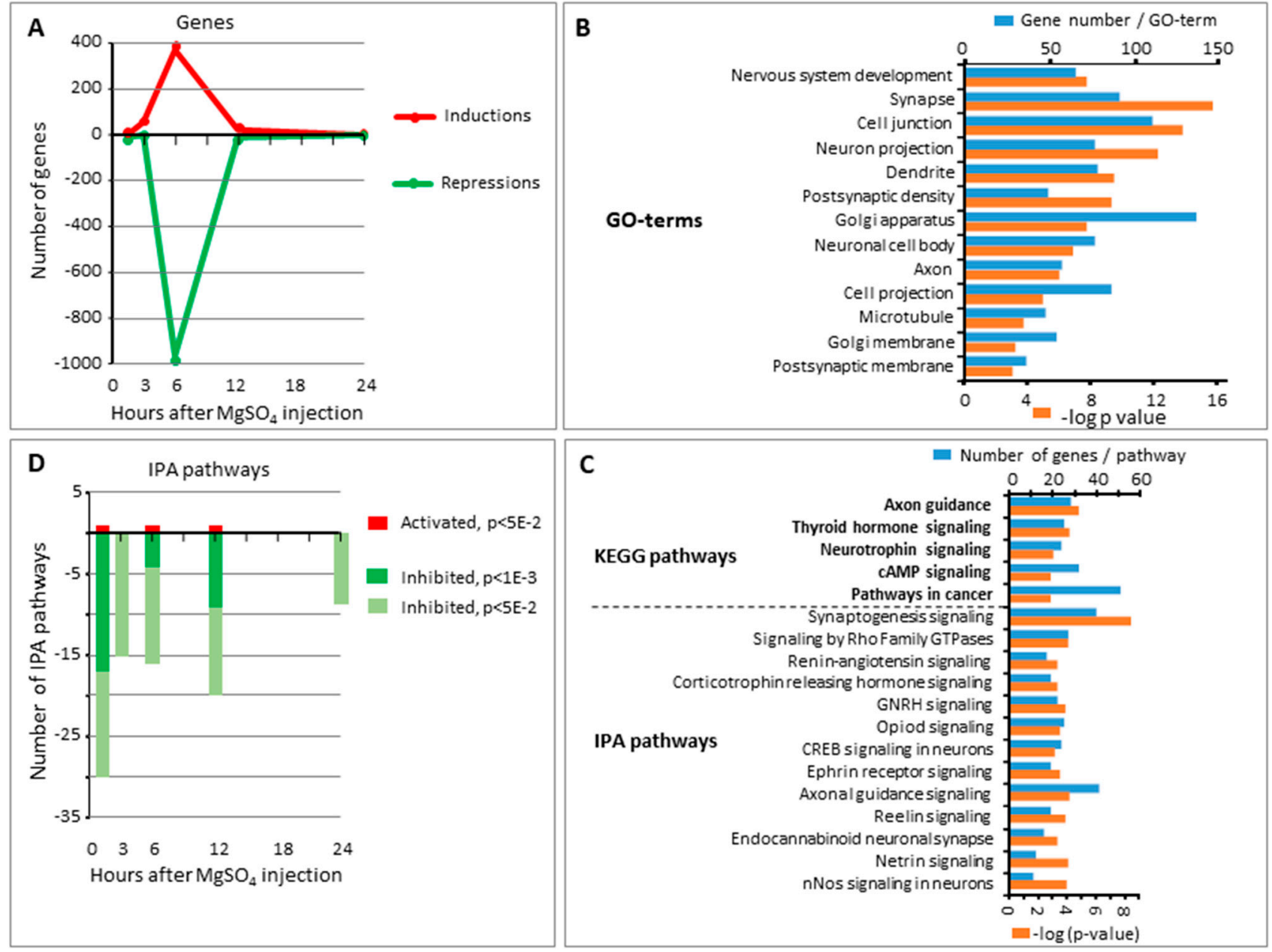

Figure 3. Effects of $\mathrm{MgSO}_{4}(600 \mathrm{mg} / \mathrm{kg})$ single injection in $\mathrm{P} 5$ mouse brain transcription. (A) Time course response on inductions (in red) and repressions (in green, labeled as negative values) showing a very transient wave of inductions and repressions centered on $6 \mathrm{~h}$ after injection time point. (B) Time course distribution of significantly enriched IPA-Pathways extracted from $\mathrm{MgSO}_{4}$ single injection. (C) Gene numbers and $\log p$-values in 13 Gene Ontology terms enriched from $1 \mathrm{~h}$ 30 min-24 h effects of $\mathrm{MgSO}_{4}$ single injection. (D) Gene numbers and $\log p$-values in Kyoto Encyclopedia of Genes and Genomes (Kegg) and IPA Pathways significantly enriched from $1 \mathrm{~h} 30 \mathrm{~min}-24 \mathrm{~h}$ effects of $\mathrm{MgSO}_{4}$ single.

\subsubsection{Up Keywords}

The highest enrichments of UP_keywords (seKws) specific to list A were noted for "synapse," "neurogenesis," and "cell junction" (Table 1). Looking at neurogenesis one could note many genes coding transcription factors, membrane associated scaffolding and cue proteins, neurotrophin transmission associated proteins. The cell junction list included all seKws associated to synapses and had $20 \%$ of genes in common with the cytoskeleton list. Enrichment of these seKws, also exhibiting very low false discovery rate (FDR) values, clearly indicated that $\mathrm{MgSO}_{4}$ targeted the transcription in neurons, inducing the repression of membrane proteins and especially of synaptic proteins. Many glutamatergic synapse elements exhibited high amplitude repression (Grin1, Shank3, Dlgap3, Dlgap1, and Slc17a7 coding the Vglut1 transporter). In addition, Grina3, Dlg2, Gria1, and Grik5, also appeared to be repressed, but with less amplitude, whereas Grik3 was induced. Repression of Ache and the muscarinic receptor M1 genes were also recorded (see details in Table S1B). 
Table 1. Keywords, GO terms and pathway enrichments after $\mathrm{MgSO}_{4}$ single injection (List A).

\begin{tabular}{|c|c|c|c|c|c|}
\hline $\begin{array}{c}\text { Up_Keywords } \\
\text { (David }^{\circledR} \text { v6.8 Analysis) }\end{array}$ & Count & $p$-Value * & Enrichment & FDR & \\
\hline Synapse & 70 & $5.08 \times 10^{-16}$ & 3.31 & $1.06 \times 10^{-16}$ & \\
\hline Neurogenesis & 48 & $3.56 \times 10^{-10}$ & 3.28 & $3.73 \times 10^{-11}$ & \\
\hline Cell junction & 102 & $2.90 \times 10^{-16}$ & 2.60 & $8.10 \times 10^{-17}$ & \\
\hline Methylation & 128 & $1.66 \times 10^{-15}$ & 2.25 & $2.31 \times 10^{-16}$ & \\
\hline Golgi apparatus & 99 & $5.52 \times 10^{-11}$ & 2.22 & $6.60 \times 10^{-12}$ & \\
\hline Cell projection & 82 & $5.09 \times 10^{-7}$ & 2.04 & $3.55 \times 10^{-8}$ & \\
\hline GO Terms (David ${ }^{\circledR}$ analysis) & Count & $p$-Value * & Enrichment & FDR & Dispensability \\
\hline GO:0045202 synapse & 91 & $2.69 \times 10^{-16}$ & 2.80 & $1.87 \times 10^{-9}$ & 0.00 \\
\hline GO:0043005 neuron projection & 75 & $1.01 \times 10^{-12}$ & 2.77 & $6.17 \times 10^{-16}$ & 0.00 \\
\hline GO:0014069 postsynaptic density & 49 & $8.14 \times 10^{-10}$ & 3.18 & $2.32 \times 10^{-12}$ & 0.04 \\
\hline $\begin{array}{c}\text { GO:0007399 nervous system } \\
\text { development }\end{array}$ & 64 & $2.94 \times 10^{-8}$ & 2.56 & $1.41 \times 10^{-8}$ & 0.00 \\
\hline $\begin{array}{c}\text { GO:0048167 regulation of synaptic } \\
\text { plasticity }\end{array}$ & 13 & $4.33 \times 10^{-2 \#}$ & 4.68 & $2.12 \times 10^{-12}$ & 0.14 \\
\hline KEGG_Pathways (DAVID ${ }^{\circledR}$ analysis) & Count & $p$-Value * & Enrichment & FDR & \\
\hline mmu04360:Axon guidance & 28 & $1.66 \times 10^{-5}$ & 3.27 & $1.36 \times 10^{-5}$ & \\
\hline $\begin{array}{l}\text { mmu04919:Thyroid hormone } \\
\text { signaling pathway }\end{array}$ & 25 & $8.09 \times 10^{-5}$ & 3.30 & $3.30 \times 10^{-5}$ & \\
\hline $\begin{array}{c}\text { mmu04722: Neurotrophin signaling } \\
\text { pathway }\end{array}$ & 24 & $1.08 \times 10^{-3}$ & 2.96 & $2.41 \times 10^{-4}$ & \\
\hline mmu04024:cAMP signaling pathway & 32 & $1.34 \times 10^{-3}$ & 2.44 & $2.41 \times 10^{-4}$ & \\
\hline mmu05200:Pathways in cancer & 51 & $1.48 \times 10^{-3}$ & 1.94 & $2.41 \times 10^{-4}$ & \\
\hline mmu04910:Insulin signaling pathway & 24 & $4.19 \times 10^{-5} \#$ & 2.58 & $1.14 \times 10^{-3}$ & \\
\hline IPA Pathways (Ingenuity analysis) & Count & $p$-Value & N Max $\$$ & Kinetics $^{£}$ & z-score \\
\hline Synaptogenesis Signaling Pathway & 40 & $4.79 \times 10^{-9}$ & $6 \mathrm{~h}$ & L (4) & -5.667 \\
\hline Reelin Signaling in Neurons & 19 & $3.16 \times 10^{-5}$ & $6 \mathrm{~h}$ & $\mathrm{~L}(2)$ & -4.000 \\
\hline Axonal Guidance Signaling & 41 & $7.08 \times 10^{-5}$ & $3 \mathrm{~h}-12 \mathrm{~h}$ & $\mathrm{~L}(2)$ & $a$ \\
\hline Signaling by Rho Family GTPases & 27 & $9.77 \times 10^{-5}$ & $6 \mathrm{~h}$ & $\mathrm{~L}(2)$ & -4.472 \\
\hline Netrin Signaling & 12 & $1.00 \times 10^{-4}$ & $6 \mathrm{~h}$ & L (3) & -3.317 \\
\hline nNOS Signaling in Neurons & 11 & $1.12 \times 10^{-4}$ & $3 \mathrm{~h}$ & $\mathrm{~L}(2)$ & -2.236 \\
\hline GNRH Signaling & 22 & $1.45 \times 10^{-4}$ & $6 \mathrm{~h}$ & $\mathrm{~L}(3)$ & -3.207 \\
\hline Ephrin Receptor Signaling & 19 & $3.09 \times 10^{-4}$ & $3 \mathrm{~h}-12 \mathrm{~h}$ & $\mathrm{~L}(2)$ & -3.873 \\
\hline Opioid Signaling Pathway & 25 & $3.63 \times 10^{-4}$ & $6 \mathrm{~h}$ & $\mathrm{E}(1)$ & -3.130 \\
\hline $\begin{array}{l}\text { Endocannabinoid Neuronal } \\
\text { Synapse Pathway }\end{array}$ & 16 & $4.68 \times 10^{-4}$ & $6 \mathrm{~h}$ & $\mathrm{E}(1)$ & -2.324 \\
\hline $\begin{array}{l}\text { Corticotropin Releasing } \\
\text { Hormone Signaling }\end{array}$ & 19 & $4.90 \times 10^{-4}$ & $6 \mathrm{~h}$ & $\mathrm{E}(1)$ & -1.897 \\
\hline Renin-Angiotensin Signaling & 17 & $5.01 \times 10^{-4}$ & $6 \mathrm{~h}$ & L (3) & -3.464 \\
\hline CREB Signaling in Neurons & 24 & $7.08 \times 10^{-4}$ & $6 \mathrm{~h}$ & $\mathrm{E}(1)$ & -3.606 \\
\hline PTEN Signaling & 15 & $8.128 \times 10^{-3}$ & $12 \mathrm{~h}$ & $\mathrm{~L}(0)$ & +2.714 \\
\hline
\end{tabular}

DAVID $^{\circledR}$ identifications of enriched KEGG pathways and Up_Keywords, based on 1411 genes. Selection of 5 nervous system-related seGO-terms exhibiting among the highest enrichments. IPA ${ }^{\circledR}$ determinations done on 1492 regulated probes exhibiting $p$-values $<1 \times 10^{-3}$ at least at one time point, with the exception of PTEN signaling, the only seIPA with a positive $\mathrm{z}$-score). ${ }^{*} t$-test $p$-value after Bonferroni correction (not for IPA analysis). ${ }^{\$}$ Max indicates the time point exhibiting the maximum number of genes in the pathway. \# italics indicate $p$-value according to Fisher exact test. ${ }^{£}$ Kinetics evaluated based on lowest IPA $p$-values $\left(<1 \times 10^{-3}\right)$ were observed at 4 out of 5 time points (none at $24 \mathrm{~h}$ ), noted as E (early) and L (lasting). Values in parentheses indicate the number of time points with $p$-values $<1 \times 10^{-3}$ ). a No z-score calculated.

\subsubsection{GO Analysis}

DAVID $^{\circledR}$ Gene Ontology identified 44 seGO-terms; 10 biological processes (BP), 24 cell components (CC), and 10 molecular functions (MF) subclasses. Five seGOterms were related to neurons, synapses nervous system development, and postsynaptic density, exhibited the highest significant $p$-values and showed among the highest number of genes involved (Table 1). With a lower significance seGO-terms also focused on cell junctions, neuron projection or ion binding, and with decreasing incidence on, kinasephosphorylation activities, the cytoskeleton, the regulation of transcription, cell signaling, 
and the Golgi apparatus (Figure 3B, Supplementary Table S1B). Those genes associated with seGO-terms mainly underwent repressions.

\subsubsection{Pathway Analyses \\ KEGG Pathways}

DAVID $^{\circledR}$ analysis allowed the extraction of 45 significantly enriched Kyoto Encyclopedia of Genes and Genomes (KEGG) pathways (seKpaths) at the Expression Analysis Systematic Explorer (EASE) $p$-value threshold $<5 \times 10^{-2}$ (and 14 others out of scope) (Supplementary Table S1C). Of note the lowest $p$-value recorded were associated to axon guidance (mmu04360, $p=1.66 \times 10^{-5}$ in Bonferroni test), thyroid hormone signaling, neurotrophin signaling, cAMP signaling, and pathways in cancer (including genes involved in extracellular matrix-cell regulation and insulin signaling (Table 1). Less significant seKPaths were related to neurotransmission systems (glutamatergic synapse, GABAergic synapse, retrograde endocannabinoid signaling, cholinergic synapse, and many peptide signaling and membrane transduction pathways (Figure 3C, Supplementary Table S1C).

\section{Ingenuity Pathway Analysis (IPA) Pathways}

Pathway extraction using IPA was based on a strictly different approach and allowed a much broader view as the strategy did not depend on previous validations, as for the KEGG pathways, which are relatively limited in mice. IPA pathways were extracted at all five time points on the corrected log ratio of the 1492 probes affected by $\mathrm{MgSO}_{4}$ injection at least at one time point. A total of 13 significantly enriched IPA pathways (seIPaths) exhibited Fisher's Exact Test $p$-value $<1 \times 10^{-3}$, of which 11 had z-score $<-2$ (Table 1, Figure 3C).

Se-IPath enrichments were noted early (1 h $30 \mathrm{~min}$ ) and exceeded what could be expected from the gene kinetics record (Figure 3D). The seIPaths exhibiting the most significant $p$-values, together with more specific genes included were synaptogenesis, reelin signaling in neurons, and axonal guidance (Table 1). Only one seIPath had a positive $p$-value (PTEN signaling) indicating an activation of the pathway, although this was exclusively based on gene repressions (Table S1D).

\section{IPA ${ }^{\circledR}$ Upstream Regulators}

Putative upstream regulators (pURs) refers to key regulators, on the basis of convergences between reports in the literature of any relationships between this gene/protein expression/activity and the enrichment of these anticipated effects in an experimental set of data. A z-score, significant when $>2$ (or $<-2$ ), indicates the sense of the regulation. When a pUR was not affected at its transcription level, one must conclude that the experimental condition had downstream effects on its translation or on the function of the coded protein. In the following text, pURs are identified using protein symbols, whereas gene symbols (in italics) refer to transcription observations. Furthermore, the terms induction and repression are devoted to transcriptions observation, whereas the effects of pUR are called activation and inhibition.

Only two pURs (Mnk1 and Frm-1) showed very highly significant $p$ value $\left(<1 \times 10^{-7}\right)$, although $\mathrm{MgSO}_{4}$ did not affect their transcription. Upstream analysis revealed inhibition of Mnk1 and activation of Fmr-1, but the putative effects of $\mathrm{MgSO}_{4}$ on downstream effects converged toward essentially the same canonical pathways, i.e., the inhibition of synaptogenesis, reelin-, and glutamate receptor signaling (Figure 4, Table S1E). The mechanism of the interaction of $\mathrm{Mg}^{2+}$ with Mnk1 and Fmr-1 remains elusive. Among the 30 genes putatively downstream to Mnk1 in the Mg group, three genes affected in HI showed reversed effects in $\mathrm{MgHI}$ (Map1b, Mapre2, Vim), 26 genes affected by $\mathrm{Mg}$ no longer appeared in $\mathrm{MgHI}$, and the four genes remaining exhibited inverted regulation (Bag3, Cplx2, Trim32, and Ttc3). 
A

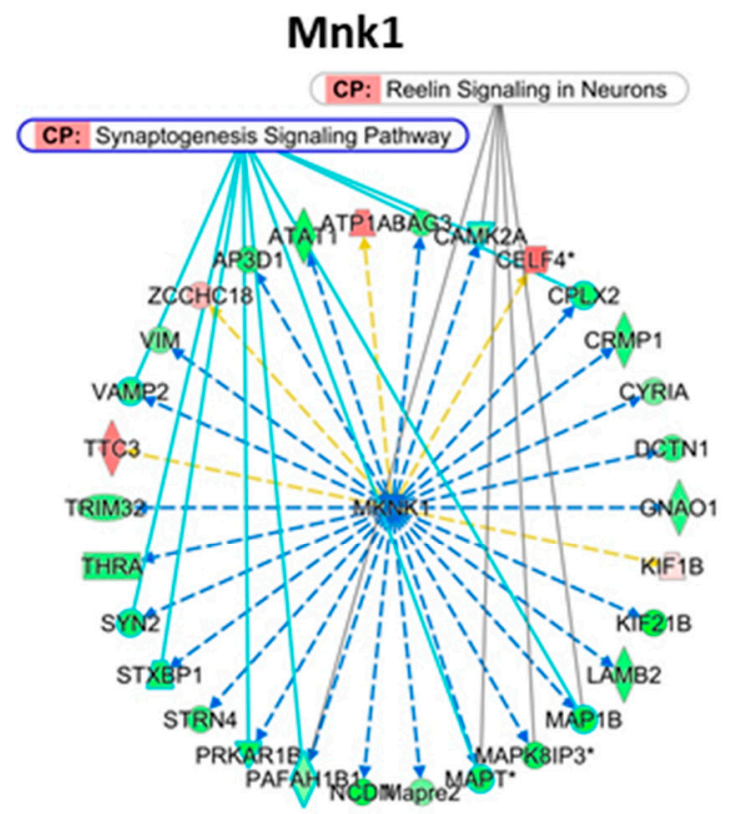

B

\section{Fmr-1}

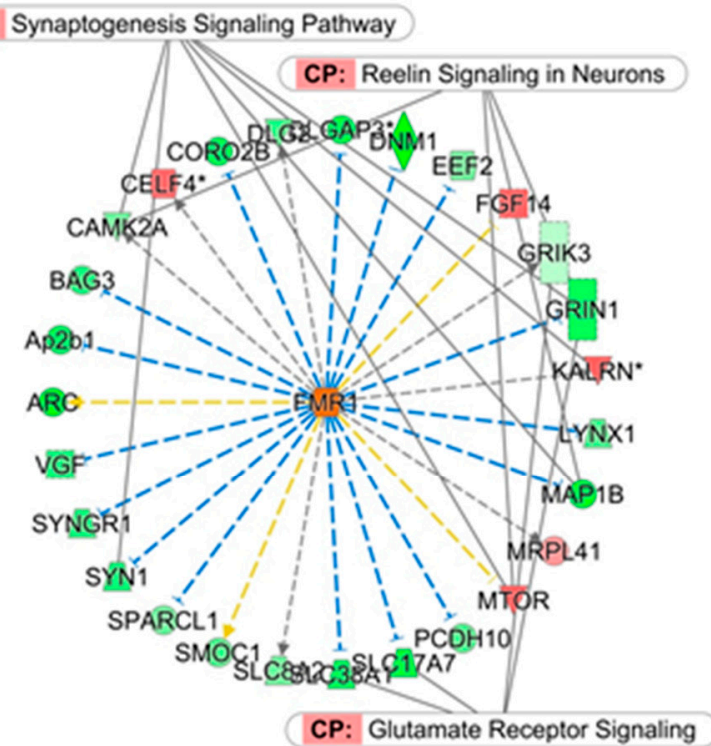

Figure 4. Schematic representation of two $\mathrm{MgSO}_{4}$ putative upstream regulators (pURs) $6 \mathrm{~h}$ after injection. Blue and orange background in pURs (centered) indicate inhibition and activation respectively. Red and green backgrounds in genes downstream to pURs indicate gene induction or repression. (A) Putative Mnk1 inhibition by $\mathrm{MgSO}_{4}$ based on 30 transcription effects recorded. (B) Putative Fmr-1 activation by $\mathrm{MgSO}_{4}$ based on 20 transcription effects recorded. Blue, yellow, and gray arrows indicate coherence, absence of coherence or undetermined sense of variation of respective genes in observations and in the literature, according to IPA ${ }^{\circledR}$ analysis. *; multiple identifiers (probes) in data list.

As a polyribosome-associated mRNA-binding protein with specific activity in brain development and synapse plasticity, Fmr-1 is an indicator of $\mathrm{Mg}$ tropism toward protein translation in neurons. Sirt1 was another, although less significant pUR, with lasting occurrence, a positive z-score, and $p<1 \times 10^{-4}$ at $24 \mathrm{~h}$, which is involved in histone de-acetylation (Table S1E).

Synthesis

$\mathrm{MgSO}_{4}$ injection mainly provoked gene repressions, which predominated even more significantly in the coordinated effects revealed by seKPaths, seIPaths, and pUR, indicating a convergent expression of activity toward two groups of functions (Figure 3B-D, Table S1).

Both seKPaths and seIPaths were related to nervous system development (axon guidance, thyroid hormone signaling, synaptogenesis signaling, reelin signaling, netrin signaling). pUR analysis pointed out Mknk1 and Fmr1 as $\mathrm{MgSO}_{4}$ targets for the cooperative inhibition of synaptogenesis, reelin, and glutamate signaling. Repressions largely predominate in these pathways, suggesting a transient brake in nervous system development (Table 1). pUR analysis suggested Frm1 as an $\mathrm{MgSO}_{4}$ target involved in the inhibition of synaptogenesis as well as implicating Sirtuin-1 as a potential site for $\mathrm{Mg}$ epigenetic activities.

A large group of seIPaths showed effects of $\mathrm{MgSO}_{4}$ effects on chemical signaling by hormones (insulin, corticoliberin, renin-angiotensin, $\mathrm{GnRH}$ ) and neurotransmission modulators (NO, Ephrin, opioids, endocannabinoids). Transduction systems were also affected (signaling by Rho GTPase and CREB). All were slowed down (z-scores $<-2$ ) at several time points indicating reduced activity.

$\mathrm{MgSO}_{4}$ affected the expression of 299 developmentally regulated genes, mainly anticipating ontogenetic increases, and to a lesser extent ontogenetic decreases of expression (Supplementary data). Very few $\mathrm{MgSO}_{4}$ effects were antagonistic to ontogeny (Supplementary Figure S2). 


\subsection{Long-Term Behavioral Effects of Neonatal $\mathrm{MgSO}_{4}$ Single Injection}

Regarding the effects of $\mathrm{MgSO}_{4}$ single injection on the expression of synaptic genes and spontaneous ontogenic evolution, there may be a concern that it could affect the brain development and result in lasting behavioral alterations. $\mathrm{MgSO}_{4}$ effects were examined in sex-separated groups in several tests, in comparison with positive control animals treated at P5 with MK-801 or ketamine. Detailed effects and statistics are given in Tables S4-S7.

\subsubsection{Spontaneous Locomotor Activity}

The activity estimated by the running distance in the free wheel showed a significant effect of sex (females were more active than males) in the two-way ANOVA. The Bonferroni post-test showed an increased activity in females treated by ketamine (Figure 5A). No differences between acutely treated neonates (BPS, MK-801, or $\mathrm{MgSO}_{4}$ ) nor in Repeat-edly treated animals ( $\mathrm{PBS}$ or $\mathrm{MgSO}_{4}$ ) were observed. It is noteworthy that repeated injection, which required daily handling in pups, had a lasting reduction effect on activity, although the nature of the treatment had no effect (Figure S3A,B, Table S4).

A

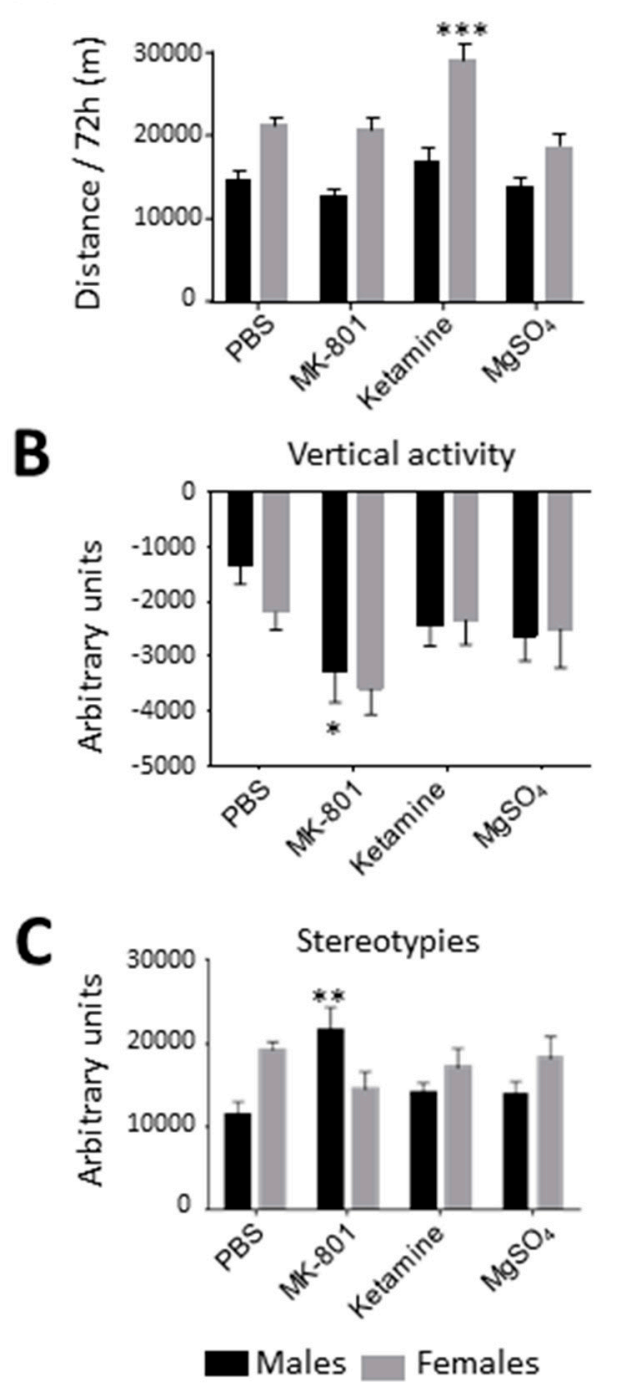

D
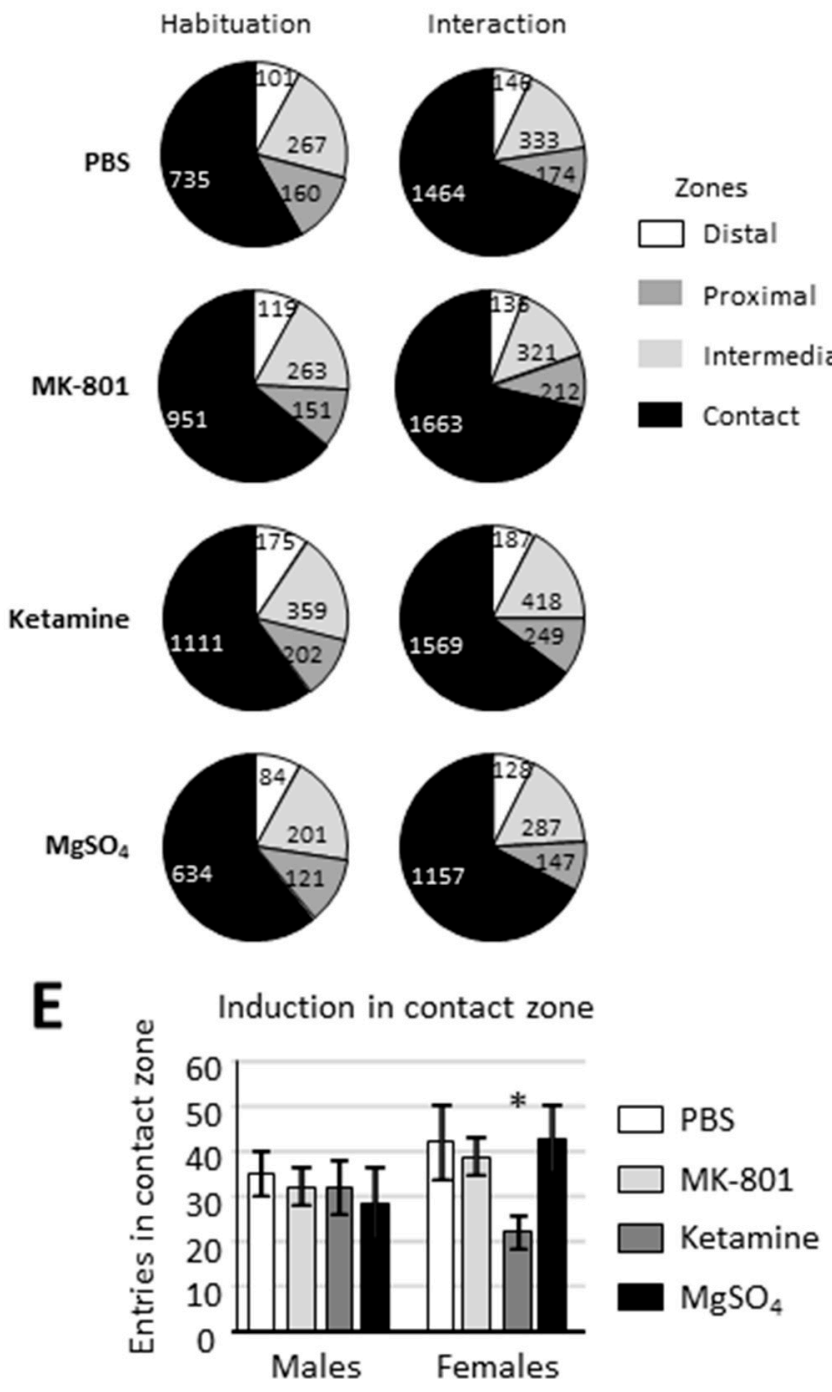

Figure 5. Behavioral effects in adulthood of P5 mice treated with PBS, MK-801, ketamine or $\mathrm{MgSO}_{4}$ at $\mathrm{P} 5$ in the running wheel (A), open field exploration (B), acute MK-801-evoked hyperactivity (C), and social interaction behavior $(\mathbf{D}, \mathbf{E}){ }^{*} p<0.05$, ${ }^{* *} p<0.01,{ }^{* * *} p<0.001$ according to two-way ANOVA Bonferroni post-test. 


\subsubsection{Open Field}

Animal Spontaneous Activity

Open field exploration was recorded for $30 \mathrm{~min}$ in the open field and was analyzed in acute or repeated treatment groups using two-way ANOVA (sex/treatment). Sex differences were observed but no effects of treatments on the distance run through the open field or on the exploration time of the central area (Figure S3C,D, Table S5).

\section{MK-801 Evoked Hyperlocomotion}

MK-801 acute injection at the end of 30 min exploration induced locomotor activation in adults in all neonatally treated groups. It induced running activity and stereotypies but reduced vertical exploration (Figure S4, Table S6). The post-test revealed that neonatal MK-801 increased vertical exploration in males $(p=0.0116)$ and had a tendency to produce the same effect in females ( $p=0.0921)$ (Figure 5B). An interaction of sex with treatment was observed in stereotypies. The post-test revealed an amplification of stereotypies induced by acute MK-801 in males $(p=0.0018)$ whereas it had a tendency to reduce them in females (Figure 5C).

\subsubsection{Social Interaction}

$\mathrm{MgSO}_{4}$ had no influence on adult behavior nor did MK-801 (Figure 5D,E). Global activity evaluated on the basis of total distance run or rearing, did not reveal differences related to acute nor repeated treatments although sex differences were observed (not shown). The time spent in the contact zone was selected as a raw index of social interaction and did not show an effect of treatment (Table S7). Tenuous treatment effects were detected using the comparison of inter-zone crossings to evaluate the activity induced by the apparition of the congener. Treatments had no effect on raw indexes according to twoway ANOVA (on sex and treatment), in acute or repeated treatment groups whereas sex effects were constant (Supplementary Table S7). The distribution of crossings did not differ between groups during habituation whereas it revealed a significant difference in females during the interaction period (Figure 5D,E, Supplementary Table S7). Neonatal ketamine affected activity provoked by an unknown congener in females $\left(\mathrm{Chi}^{2}=31.15_{\mathrm{df} 3}, p=0.0003\right)$. The reduced number of entries evoked by the congener did not necessarily reflect a poor interest for the congener since time spent in the contact zone was not reduced in these ketamine-treated females (Supplementary Table S7)). Thus, the experimental paradigm appeared to be discriminant, and did not show any effect of $\mathrm{MgSO}_{4}$ on this behavior, even after repeated neonatal administrations.

\subsubsection{Synthesis}

MK-801 or ketamine, used as positive controls, induced sex-dependent effects in the different behavior tests. This selectivity of MK-801 and ketamine among tests and sex reinforces the choice of the tests as they appeared to be relevant for distinct behavioral traits. In addition, they showed ketamine effects that were independent of glutamate NMDA receptor subtype blocking, since they were distinct from the effects of MK-801. The question of long-term effects of single neonatal ketamine exposure is once again addressed. Of note, neonatal acute or even repeated $\mathrm{MgSO}_{4}$ neonatal single injection did not alter any of this series of independent behavioral traits (Figures S3 and S4).

\subsection{Interaction of $\mathrm{MgSO}_{4}$ with HI-Induced Transcriptional Modulation}

\subsubsection{General Observations}

The modulation by $\mathrm{MgSO}_{4}$ of the effects of $\mathrm{HI}$ did not result from the differences observed in experiment 2; therefore, we must take into account the effects of $\mathrm{HI}$ unaffected by $\mathrm{MgSO}_{4}$ and reciprocally the $\mathrm{MgSO}_{4}$ effects observed after $\mathrm{HI}$ (Figure 2).

The $\mathrm{MgHI}$ effects did not appear as a superposition of the separate effects of $\mathrm{MgSO}_{4}$ and of HI. The major proportion of regulated genes was specific to one of the three experimental conditions (two-color analyses of experiments 1-3). The list of $\mathrm{MgHI}$ vs. 
HI effects (list (2)) showed only 145 genes in common with that of Mg effects (List (1)), and 89 genes in common with that of HI effects (List (3) ) (20.1\% and $12.8 \%$ of (2), respectively). A similar observation was made when comparing MgHI vs. Ctrl (List (7)) in one-color analysis (Figure 6A).

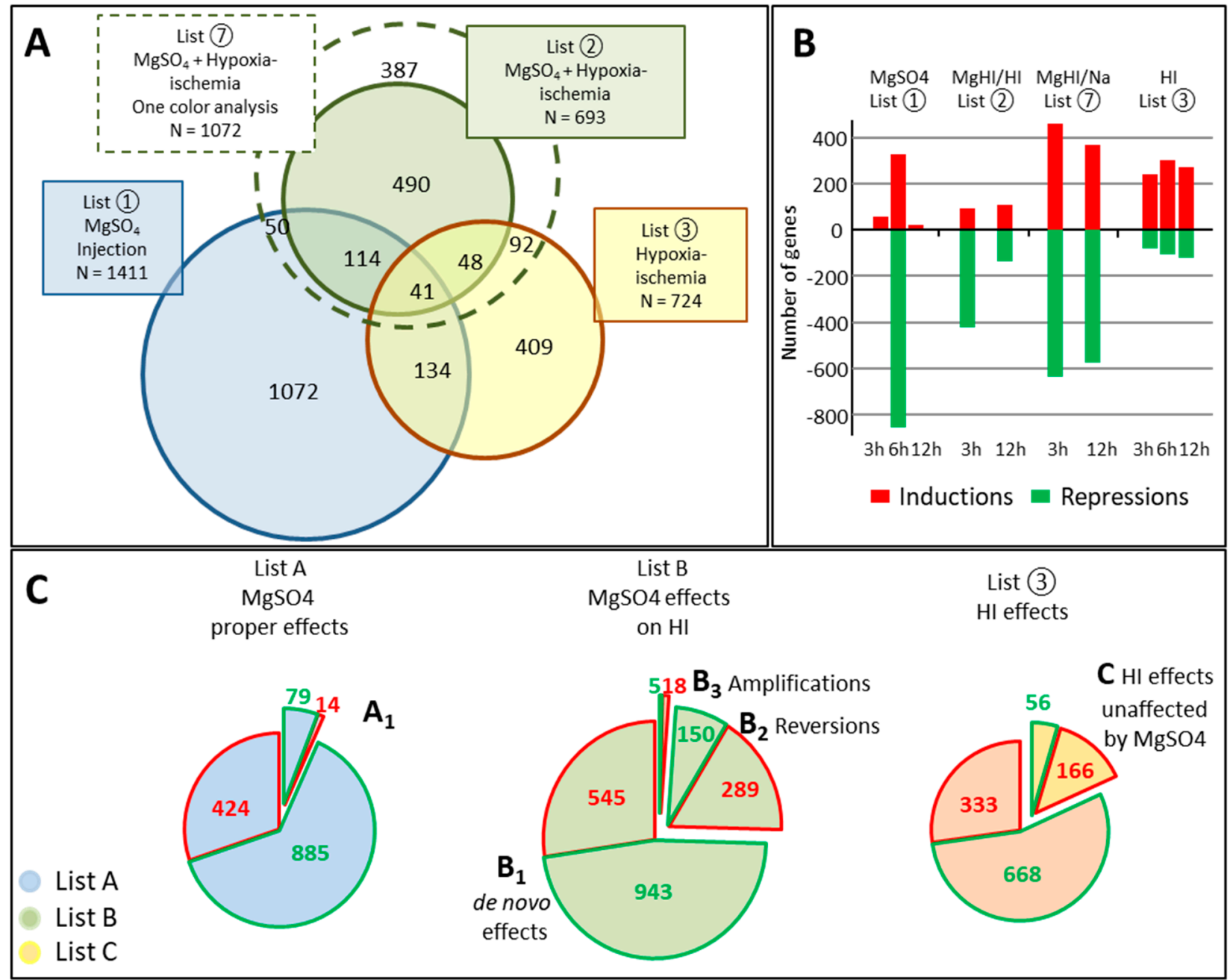

Figure 6. Comparative distribution of transcription effects of $\mathrm{HI}$ and/or $\mathrm{MgSO}_{4}$ in time and senses of effects. (A) Venn representation of coincidences in lists (1), (2), and (3). The superimposed dashed circle represents the number of genes in the one-color analysis of $\mathrm{MgSO}_{4}$ effects in $\mathrm{HI}$ (List (7)). Note that the intersection of (1), (7), and (3) included only 31 genes (not shown). (B) Kinetics of inductions (red histograms) and repression (green histograms) at $3 \mathrm{~h}, 6 \mathrm{~h}$, and $12 \mathrm{~h}$ after $\mathrm{MgSO}_{4}$, HI, or both (Lists (1), (3), and (2), respectively) from two-color analyses and MgHI effects in single-color analysis (List (7)). (C) Comparison of $\mathrm{HI}$ effects in $\mathrm{Ctrl}$ (3) and in $\mathrm{MgSO}_{4}$-pretreated (List B) mice at P5. Color circling and numbering in red and green signify inductions and repressions, respectively. Surfaces are proportional to numbers (superposition surfaces approximate numbers). Red and green circling in List $\mathrm{B} 2$ of $\mathrm{HI}$ regulations reversed by $\mathrm{MgSO}_{4}$ are indicative of $\mathrm{MgSO} 4$ effects. Biphasic or putatively spliced genes were not taken into account in $\mathrm{B}_{1}$ and $\mathrm{B}_{2}$ representations. List numberings refer to Figure 2.

$\mathrm{MgSO}_{4}$ pretreatment induced more negative regulations than enhancement of expressions due to $\mathrm{HI}$ in the $\mathrm{P} 5$ mouse brain (513 vs. 180 in list (2)). It modified the transcription response as early as $3 \mathrm{~h}$ after $\mathrm{HI}$, i.e., before showing proper transcription effects (peak at $6 \mathrm{~h}$ ), indicating that before magnesium had transcriptional effects, it affected effector systems (e.g., enzyme activities), which in turn largely modified the whole transcription response to $\mathrm{HI}$. Much fewer genes continued to have an altered expression $12 \mathrm{~h}$ after $\mathrm{MgHI}$, 
and most showed a reduction of an effect already seen at $3 \mathrm{~h}$, indicating the short-term biological response (Figure 6B).

$\mathrm{MgSO}_{4}$ also evoked de novo HI-inductions $(n=545)$ and repressions $(n=943)$ revealed by one-color analyses (List $\mathrm{B}_{1}$ ), confirming that $\mathrm{MgSO}_{4}$ rather than preventing the $\mathrm{HI}$ response, oriented the $\mathrm{HI}$ transcription response in a new direction (Figure $6 \mathrm{C}$ ).

The assembly of $\mathrm{MgSO}_{4}$ effects in $\mathrm{HI}$ (List B) results from the summation of de novo inductions (repressions) compared to $\mathrm{HI}$ (List $\mathrm{B}_{1}$ ), as well as reversions (List $\mathrm{B}_{2}$ ), and amplifications of $\mathrm{HI}$ effects (List $\mathrm{B}_{3}$ ). From these the effects of $\mathrm{MgSO}_{4}$ that were unchanged in the $\mathrm{MgHI}$ groups (list $\mathrm{A}_{1}$ ) must be subtracted. Thus, the analysis was complex, as the different lists resulted from different kinds of data extraction. List B describes $\mathrm{MgSO}_{4}$ modulation of the HI transcription response. A total of 1964 genes in $\mathrm{MgHI}$ (842 inductions, 1091 repressions and 31 biphasic evolution or putatively spliced) showed effects that differed from $\mathrm{HI}$ effects. Repressions predominated (55.6\%), much more than in HI effects in list (3) (30.7\%), but somewhat less than in List A of $\mathrm{MgSO}_{4}$ proper effects (68.5\%) (Figure S5A). The comparison of List B with $\mathrm{HI}$ effects (List (3)) revealed a minority of genes regulated in both conditions (171 on 723 in (3)), and 1488 genes affected de novo (Figure S5B).

A small proportion of $\mathrm{HI}$ effects $(18.2 \%)$ were unaffected by $\mathrm{MgSO}_{4}$ pretreatment (List C) (Figure 6C). Even based on the restrained gene series presented in list C, David ${ }^{\circledR}$ analysis showed the persistence of major HI effects on BP seGOterms (response to cytokine, transcription from RNA polymerase II promoter, cytokine chemotaxis, DNA-templated transcription, positive regulation of gene expression, and negative regulation of neuron apoptotic process) (see below).

\subsubsection{DAVID ${ }^{\circledR}$ Biostatiscal Analyses}

Up Keywords

David $^{\circledR}$ extraction identified 18 seKws from List B, including 1576 genes $(80.2 \%$ of the total List B). The most enriched seKws were mitochondrion $(n=176)$, mitochondrion inner membrane $(n=45)$, and electron transport $(n=22)$, ribonucleoproteins $(n=54)$ and ribosomal proteins $(n=38)$ (Table 2). Repressions predominated in mitochondrion- and ribosome-seKws (77.2\% and 90.7\%, respectively). Conversely, inductions in seKws were mainly related to ubiquitination, transcription, apoptosis, and transport (Table S2B).

Four seKws were enriched from both List A and List B, referring to basic mechanisms (phosphoproteins, alternative splicing, Ubl-conjugation and transcription regulation). These few seKws included hundreds of genes in A or B, but about $10 \%$ of these genes were common to Lists A and B, 7-8\% of which even behaved in opposite direction. Many of the seKws from List $B$ were also enriched, due to de novo effects (List $\left.B_{1}\right)$ and consisted of repressions (Table $\mathrm{S} 2 \mathrm{~B}$ ).

Reversion by $\mathrm{MgSO} 4$ of $\mathrm{HI}$ effects ( $\mathrm{Lis}_{2}$ ) exhibited seKws in the fields of the major effects of HI; i.e., inflammation, immunity, and regulation of transcription by RNApolymerase II. Whether these effects underlie neuroprotection by $\mathrm{MgSO}_{4}$ requires further studies.

Altogether, these observations indicate that $\mathrm{MgSO}_{4}$ did not so much change the nature of the $\mathrm{HI}$ transcription response, but rather it profoundly modified tissue adaptation to injury. 
Table 2. Gene ontology, pathway, and keyword analyses of $\mathrm{MgSO}_{4}$ in $\mathrm{HI}$-exposed brains (List B).

\begin{tabular}{|c|c|c|c|c|c|}
\hline Up_Keywords (David ${ }^{\circledR}$ v6.8 Analysis) & Count & $p$ Value * & Enrichment & FDR & $\begin{array}{l}\text { Occurrences in } \\
\text { Separate Lists }\end{array}$ \\
\hline Phosphoprotein & 808 & $5.62 \times 10^{-36}$ & 1.44 & $4.8907 \times 10^{-36}$ & (3) \\
\hline Acetylation & 417 & $2.01 \times 10^{-34}$ & 1.81 & $8.7658 \times 10^{-35}$ & B1 \\
\hline Mitochondrion & 176 & $1.88 \times 10^{-22}$ & 2.26 & $5.4559 \times 10^{-23}$ & B1 \\
\hline Cytoplasm & 483 & $5.33 \times 10^{-20}$ & 1.49 & $1.1589 \times 10^{-20}$ & \\
\hline Nucleus & 470 & $4.63 \times 10^{-14}$ & 1.41 & $1.0989 \times 10^{-14}$ & \\
\hline Transit peptide & 77 & $1.26 \times 10^{-6}$ & 2.05 & $1.5622 \times 10^{-7}$ & B1 \\
\hline Ribonucleoprotein & 54 & $2.42 \times 10^{-6}$ & 2.38 & $2.4390 \times 10^{-7}$ & B1 \\
\hline Activator & 88 & $2.52 \times 10^{-6}$ & 1.91 & $2.4390 \times 10^{-7}$ & $\mathrm{~B} 1, \mathrm{~B} 2,(3)$ \\
\hline Apoptosis & 71 & $2.67 \times 10^{-5}$ & 1.97 & $2.3265 \times 10^{-6}$ & (3) \\
\hline Mitochondrion inner membrane & 45 & $3.80 \times 10^{-5}$ & 2.40 & $3.0111 \times 10^{-6}$ & B1 \\
\hline Ribosomal protein & 38 & $1.07 \times 10^{-4}$ & 2.54 & $7.7357 \times 10^{-6}$ & B1 \\
\hline Transport & 198 & $1.70 \times 10^{-4}$ & 1.41 & $1.1405 \times 10^{-5}$ & \\
\hline Transcription regulation & 187 & $4.06 \times 10^{-4}$ & 1.41 & $2.5221 \times 10^{-5}$ & (3) \\
\hline Ubl conjugation & 161 & $5.29 \times 10^{-4}$ & 1.45 & $3.0714 \times 10^{-5}$ & \\
\hline Transcription & 191 & $6.93 \times 10^{-4}$ & 1.39 & $3.7742 \times 10^{-5}$ & \\
\hline Electron transport & 22 & $3.06 \times 10^{-5 \#}$ & 2.79 & $5.2884 \times 10^{-4}$ & B1 \\
\hline Translocation & 18 & $4.27 \times 10^{-5 \#}$ & 3.13 & $7.0459 \times 10^{-4}$ & B1 \\
\hline \multicolumn{6}{|l|}{$\mathrm{BP}$} \\
\hline GO:0006915 apoptotic process & 84 & $1.58 \times 10^{-5 \#}$ & 1.60 & $7.12 \times 10^{-12}$ & \\
\hline \multicolumn{6}{|l|}{ CC } \\
\hline GO:0005739 mitochondrion & 282 & $2.61 \times 10^{-21}$ & 1.80 & $2.53 \times 10^{-21}$ & B1 \\
\hline GO:0005737 cytoplasm & 776 & $1.10 \times 10^{-16}$ & 1.29 & $5.33 \times 10^{-17}$ & \\
\hline GO:0005634 nucleus & 703 & $1.75 \times 10^{-13}$ & 1.28 & $4.42 \times 10^{-14}$ & B1 \\
\hline GO:0070062 extracellular exosome & 345 & $1.36 \times 10^{-9}$ & 1.42 & $3.29 \times 10^{-10}$ & \\
\hline GO:0005829 cytosol & 248 & $2.31 \times 10^{-9}$ & 1.53 & $4.48 \times 10^{-10}$ & B1 \\
\hline $\begin{array}{l}\text { GO:0030529 intracellular } \\
\text { ribonucleoprotein complex }\end{array}$ & 64 & $2.48 \times 10^{-6}$ & 2.20 & $4.01 \times 10^{-7}$ & B1 \\
\hline GO:0016020 membrane & 746 & $1.02 \times 10^{-5}$ & 1.17 & $1.41 \times 10^{-6}$ & B1 \\
\hline GO:0005840 ribosome & 43 & $2.62 \times 10^{-5}$ & 2.52 & $3.18 \times 10^{-6}$ & B1 \\
\hline \multicolumn{6}{|l|}{ MF } \\
\hline GO:0005515 protein binding & 477 & $1.40 \times 10^{-6}$ & 1.27 & $1.40 \times 10^{-6}$ & \\
\hline GO:0044822 poly(A) RNA binding & 161 & $5.94 \times 10^{-6}$ & 1.57 & $2.97 \times 10^{-6}$ & B1 \\
\hline KEGG_Pathways (DAVID ${ }^{\circledR}$ analysis) & Count & $p$ value & Enrichment & FDR & \\
\hline mmu03010:Ribosome & 30 & $5.46 \times 10^{-5 \#}$ & 2.22 & 0.0120 & B1 \\
\hline mmu05012:Parkinson's disease & 30 & $9.13 \times 10^{-5 \#}$ & 2.16 & 0.0120 & B1 \\
\hline IPA Pathways & Count & $p$ value & $\operatorname{Max} \$$ & Kinetics ${ }^{£}$ & z-score \\
\hline Reelin Signaling in Neurons & 13 & $2.40 \times 10^{4}$ & $3 \mathrm{~h}$ & $3 \mathrm{~h}-12 \mathrm{~h}$ & -3.317 \\
\hline $\begin{array}{l}\text { Role of NFAT in Regulation of the } \\
\text { Immune Response }\end{array}$ & 14 & $2.51 \times 10^{3}$ & & $3 \mathrm{~h}$ & -3.051 \\
\hline Molecular Mechanisms of Cancer & 20 & $1.05 \times 10^{2 \#}$ & & $3 \mathrm{~h}$ & $a$ \\
\hline CXCR4 Signaling & 11 & $1.29 \times 10^{2 \#}$ & & $3 \mathrm{~h}$ & -2.646 \\
\hline $\begin{array}{c}\text { Endocannabinoid Cancer Inhibition } \\
\text { Pathway }\end{array}$ & 10 & $1.45 \times 10^{2 \#}$ & & $3 \mathrm{~h}$ & $a$ \\
\hline Insulin Receptor Signaling & 10 & $1.51 \times 10^{2 \#}$ & & $3 \mathrm{~h}$ & -1.897 \\
\hline Clathrin-mediated Endocytosis Signaling & 12 & $1.58 \times 10^{2 \#}$ & & $3 \mathrm{~h}$ & $a$ \\
\hline Clathrin-mediated Endocytosis Signaling & 12 & $1.58 \times 10^{2 \#}$ & & $3 \mathrm{~h}$ & $a$ \\
\hline ILK Signaling & 12 & $1.62 \times 10^{2} \#$ & & $3 \mathrm{~h}$ & $a$ \\
\hline cAMP-mediated signaling & 14 & $2.14 \times 10^{2 \#}$ & & $3 \mathrm{~h}$ & $a$ \\
\hline B Cell Receptor Signaling & 12 & $2.24 \times 10^{2 \#}$ & & $3 \mathrm{~h}$ & -3.317 \\
\hline Systemic Lupus Erythematosus Signaling & 12 & $2.95 \times 10^{2 \#}$ & & $3 \mathrm{~h}$ & $a$ \\
\hline Ephrin Receptor Signaling & 13 & $3.24 \times 10^{2 \#}$ & $3 \mathrm{~h}$ & $3 \mathrm{~h}-12 \mathrm{~h}$ & -3.162 \\
\hline Synaptogenesis Signaling Pathway & 18 & $3.31 \times 10^{2 \#}$ & $3 \mathrm{~h}$ & $3 \mathrm{~h}-12 \mathrm{~h}$ & -3.3 \\
\hline
\end{tabular}

DAVID $^{\circledR}$ identifications of enriched KEGG pathways and Up_Keywords was based on the 1958 genes, and IPA ${ }^{\circledR}$ determinations were done on the 725 regulated probes of List (2). ${ }^{*} p$-values after Bonferroni correction, ${ }^{\#} p$-values according to Fisher exact test. ${ }^{\$}$ Time point record of maximum number of genes in the pathway. ${ }^{£}$ IPA enrichment was observed at the 3-h and/or 12-h time points. a No z-score calculated. 


\section{GO Analysis}

DAVID $^{\circledR}$ extraction of seGO-terms from List B identified eight CC-seGO-terms and two MF-seGO-terms (Table 2). The terms "mitochondrion" and "ribosome" exhibited high counts and the lowest $p$-values $\left(<1 \times 10^{-20}\right)$, although their enrichment were modest (Table S2C). Most of these terms appeared from list B1 of de novo effects, indicating that $\mathrm{MgSO}_{4}$ pretreatment allowed $\mathrm{HI}$ to affect mitochondria and ribosome related genes. The question of whether effects at these sites could account for neuroprotection by $\mathrm{MgSO}_{4}$ would be worth investigating. Nevertheless, and even if they were scarce, enriched BP and MF seGO-terms do not indicate major modification in cell functions.

\section{KEGG Pathways}

Two seKpaths were extracted from List B $\left(p<1 \times 10^{-4}\right.$ in Fisher exact test and FE $\left.>2\right)$; ribosome and Parkinson's disease, each including 30 genes (Table S8).

\subsubsection{IPA Biostatistical Analyses}

IPA Pathways in MgHI Mice

IPA $^{\circledR}$ analysis of List B could not be performed as this list resulted from lists obtained using two-color and one-color data, in distinct Genespring ${ }^{\circledR}$ standardizations. However, separated approaches toward the $\mathrm{MgSO}_{4}$ interference with $\mathrm{HI}$ transcription were carried out in two-color $\mathrm{MgHI}$ vs. HI (List (2) and one-color $\mathrm{MgHI}$ vs. Ctrl (List (7)) analyses (Figure 7).

Only one seIPath (reelin signaling in neurons) reached the $1 \times 10^{-4} p$-value from List (2) at $3 \mathrm{~h}$ (Supplementary Table S2E). Several pathways (i.e., synaptogenesis signaling pathways) had $p$-values below $1 \times 10^{-2}$ and significant $z$-scores $(<-2)$, although they included modest gene numbers. Of note reelin and synaptogenesis signaling pathways were also enriched by the effects of $\mathrm{MgSO}_{4}$ alone. No seIPaths were extracted from list (2) at the 12-h time point.

$\mathrm{IPA}^{\circledR}$ analysis of $\mathrm{MgSO}_{4}$ effects on $\mathrm{HI}$ response evaluated based on one color analysis (List (7)) revealed only one seIPath with $p<1 \times 10^{-4}$ (the sirtuin signaling pathway), although with no clear indication of regulation sense $(z=1)$. Less significant, although clearly inhibited, was EIF2 signaling which included 26 genes $\left(p=1.82 \times 10^{-4}, z=-3.051\right)$. Repression (more than 75\%) affected 15 ribosomal proteins, indicating an inhibition of protein translation in $\mathrm{MgHI}$ conditions. This inhibition of translation appeared de novo after $\mathrm{HI}$ and $\mathrm{MgSO}_{4}$ pretreatment since 28 of these genes plus four others, associated to EIF4 signaling, were not affected in the absence of pretreatment (HI in list (3)). Other de novo pathways were detected, i.e., the lasting repression of glutathione redox reactions I, and melatonin- and CDK5-signaling (Table S2E). 

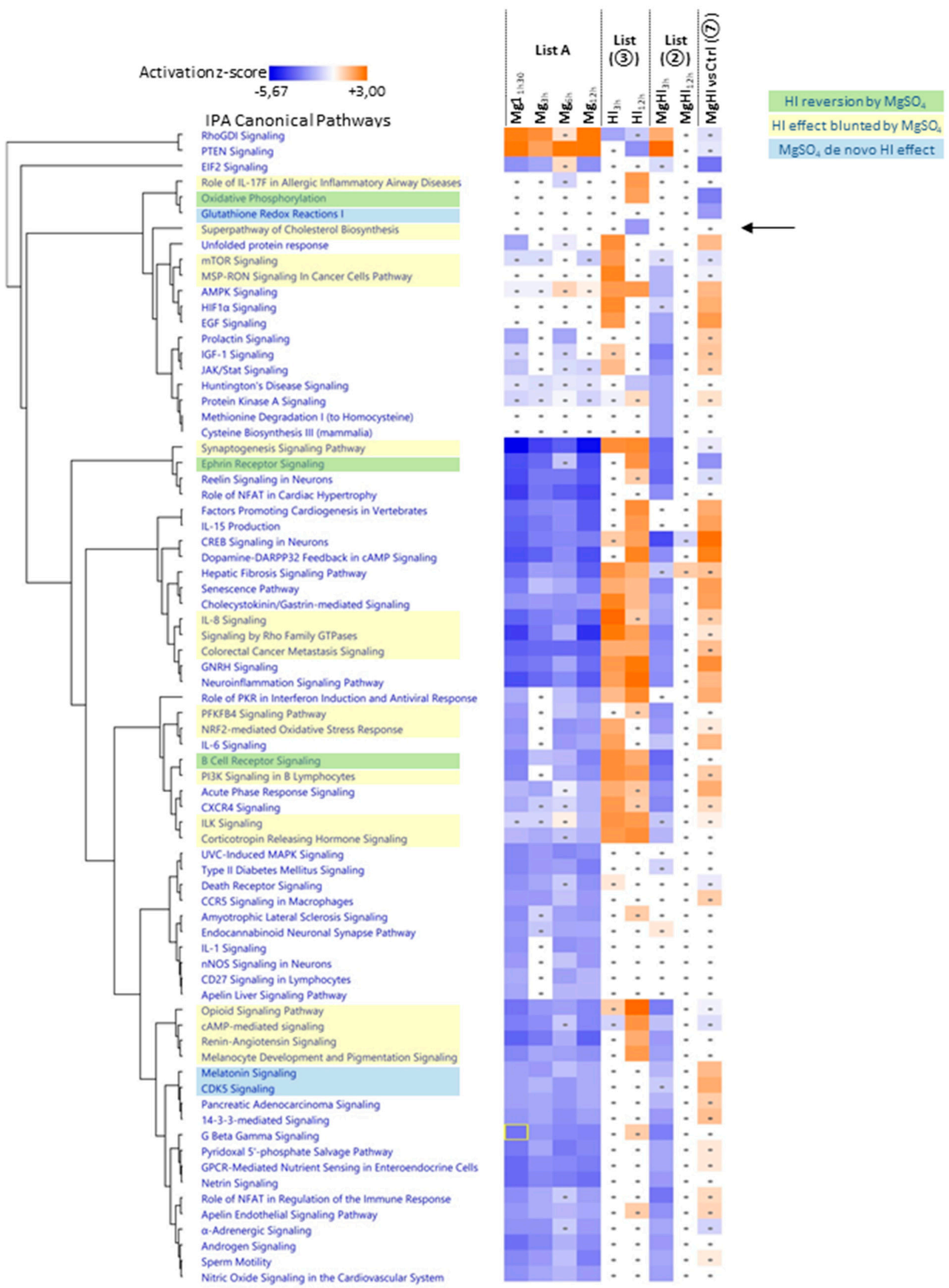

Figure 7. Comparative IPA analysis and time courses of pathways enrichment after $\mathrm{HI}, \mathrm{MgHI}$ and in both conditions. Significant enrichment of IPA pathways was examined $3 \mathrm{~h}$ and $12 \mathrm{~h}$ after insult. Thresholds were fixed a $p$-value $<5 \times 10^{-2}$, and z-score $>|1.75|$. Colored backgrounds indicate special interest seIPaths. Arrow indicates the very specific $\mathrm{HI}$ effect at $12 \mathrm{~h}$ on the superpathway of cholesterol biosynthesis. 


\section{IPA ${ }^{\circledR}$ Upstream Regulators in MgHI Conditions}

The identification of pUR in the experimental condition combining $\mathrm{MgSO}_{4}$ treatment and $\mathrm{HI}$ would not reveal a target, as would be the case in single pharmacological conditions. Rather, it would indicate putative hubs affected by the combined effects of the two stimuli which would not represent a simple summation of effects. No pUR could be extracted from the two-color analyses of $\mathrm{MgHI}$ vs. HI effects at $3 \mathrm{~h}$ or at $12 \mathrm{~h}$, possibly because of small sizes of the lists. pUR extraction from one-color analysis of MgHI vs. Ctrl (List (7) identified three pURs at highly significant $p$ values $<1 \times 10^{-4}$; two pURs were activated (Rictor and Creb-1) and one was inhibited (Tfrc) (Figure 8A, Table S2E).

A

$$
\text { mTORC2 (Rictor) (MgHI) }
$$

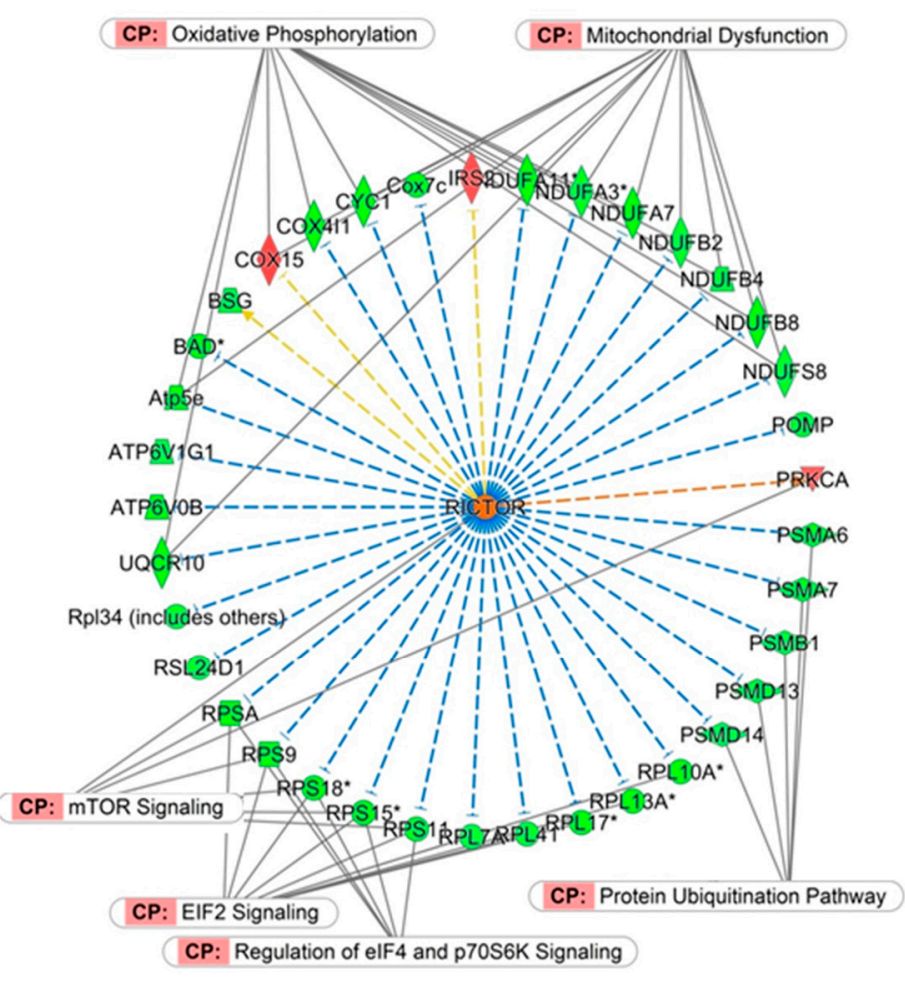

B
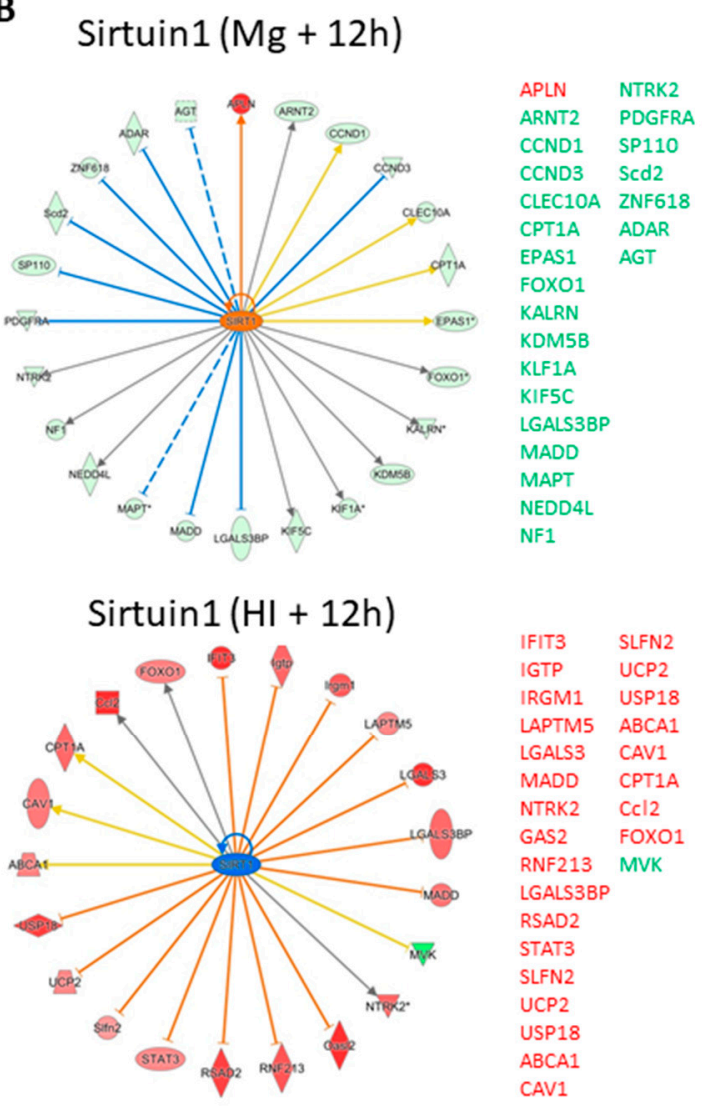

Figure 8. Putative upstream regulators in MgHI. (A) Activation of mTORC2 (coded by Rictor) as a pUR $\left(p=4.7 \times 10^{-6}\right.$, $\mathrm{z}=4.885$ ) as an effect of $\mathrm{MgSO}_{4}$ observed after $\mathrm{HI}$ in List $\mathrm{B}$, and based on 34 gene repressions and 3 inductions. This series of gene contributed to several canonical pathways $(\mathrm{CP})$ associated with $M$ tor signaling, mitochondrial dysfunction, oxidative phosphorylation, ubiquitination pathway, and protein translation by elongation factors Eif2 and Eif4. (B) Activation of sirtuin-1 (coded by Sirt1) at $12 \mathrm{~h}$ after $\mathrm{MgSO}_{4}$ injection (upper panel) or inhibition $12 \mathrm{~h}$ after $\mathrm{HI}$ (lower panel) and resulting in the opposite gene repressions (in green on lists on the right) or inductions (in red on lists on the right). *; multiple identifiers (probes) in data list.

\subsection{Tracking of Magnesium Targets}

We compared, seIPaths in nine separate conditions- $-\mathrm{MgSO}_{4}$ effects at $1 \mathrm{~h} 30 \mathrm{~min}, 3 \mathrm{~h}$, $6 \mathrm{~h}$ and $12 \mathrm{~h}, \mathrm{HI}$ effects at $3 \mathrm{~h}$ and $12 \mathrm{~h} ; \mathrm{MgHI}$ vs. HI effects at $3 \mathrm{~h}$ and $12 \mathrm{~h}$ (List (2) and $\mathrm{MgHI}$ vs. Ctrl effects using the one-color approach (list (7) (Figure 7).

\subsubsection{Effects of $\mathrm{MgSO}_{4}$ Injection}

Fmr1 and Mnk1 were two pURs among the effects of $\mathrm{MgSO}_{4}$ (Figure 4 and Figure S6). In $\mathrm{Mg}$, 23 of the 30 genes under the Mnk1putative upstream inhibitor were specifically associated to this pUR. They were not significant pUR in HI, but Fmr1 and Mnk1 showed inverted z-score and nearly significant $p$-values in the one-color $\mathrm{MgHI}$ analysis. Reciprocal 
activation of Fmr-1 as a pUR in Mg appeared far less significant in MgHI at $3 \mathrm{~h}$ and was possibly reversed in one-color analysis (Tables S1E and S2E). Owing to its recurrent and highly significant enrichment, it appears to be a highly likely target on which $\mathrm{MgSO}_{4}$ had an inhibitory effect, downstream to transcription. However, as almost no pUR downstream gene were affected in $\mathrm{HI}$, the regulation on $\mathrm{Mnk} 1$ and $\mathrm{Fmr} 1$ by $\mathrm{MgSO}_{4}$ has probably no direct effect on neuroprotection.

Casr, Sirt1, and IL4 appeared to be lowly significant pURs in mice treated solely with $\mathrm{MgSO}_{4}$. All three were highly significant potential hubs in $\mathrm{HI}$ but these putative activities did not remain in $\mathrm{MgSO}_{4}$-pretreated animals (Tables S1E and S2E,F).

\subsection{2. pURs Extracted from the Panel of Genes Affected after HI}

IPA $^{\circledR}$ extraction allowed us to identify 48 pURs with $p$-values below $1 \times 10^{-4}$ (Table S2F). A high number of pURs in HI had disappeared in MgHI group. As the majority of pURs in $\mathrm{HI}$ were related to inflammation, acute reaction and transcription one could expect $\mathrm{MgSO}_{4}$ effects to point in these directions, although we could not identify specific targets at this point. Only three of these 48 pURs appeared in the Mg group (Crem, Casr and Sirt1), and did not remain in MgHI. However, it seems unlikely that these effectors are $\mathrm{MgSO}_{4}$ targets since the majority of their downstream-targeted genes had expression patterns that were unchanged in MgHI, compared to HI conditions (31/54) (Table S2E,F).

\subsubsection{Effects of Combined MgHI Conditions}

Many seIPaths appeared to be affected with different kinetics, in opposite sense in $\mathrm{Mg}$ or HI groups (Figures S8 and S9). Among them, several showed Mg-like or HI-like effects in $\mathrm{MgHI}$, whereas others disappeared. The inversion of $\mathrm{HI}$ activation in $\mathrm{MgHI}$ was noted for oxidative phosphorylation, ephrin receptor signaling, and B-cell receptor signaling (Figure 7). Abolitions of HI activation were noted for mTOR signaling, hepatic fibrosis signaling, and ILK signaling. The highly significant inhibition of the super-pathway of cholesterol biosynthesis observed $12 \mathrm{~h}$ after $\mathrm{HI}$ also disappeared in $\mathrm{MgHI}$.

Several apparent discordances appeared between $\mathrm{MgHI}$ vs. HI effects and $\mathrm{MgHI}$ vs. Ctrl effects, likely due to the different timing of evaluation, and the occurrence of transient responses (Figure 7). Indeed, the rapid bio-availability of $\mathrm{Mg}^{2+}$ and its rapid clearance may have short-term effects that do not last or are overwhelmed by HI effects. Thus, comparing pURs in the nine lists, we could classify the observations in four groups. Only one gene/protein (Rictor) appeared as a de novo pUR in MgHI. Three pURs exhibited opposite z-scores in the $\mathrm{Mg}$ and $\mathrm{HI}$ groups, resulting in annihilation or $\mathrm{HI}$ reversion effects in MgHI (Casr, Ppara and Fmr1). In addition, larger series with less clear patterns regrouped pUR in $\mathrm{HI}$ for which $\mathrm{MgSO}_{4}$ prevented $(n=68)$ or did not affect $(n=48)$ their significance in MgHI (Table S2E). These series contain many genes involved in effectors in inflammation, cell death, transcription, and DNA repair, indicating that $\mathrm{MgSO}_{4}$ in fact reduced these effects, although the analysis pointed out few specific putative $\mathrm{Mg}$ targets for these effects. Five entities, however, retained our attention-Rictor, Infg, Il4, Ppara, and Sirt1.

Rictor expression was unaffected in all conditions. mTORC2, coded by Rictor appeared to be a de novo pUR, based on de novo gene regulations in $\mathrm{MgHI}$ conditions. It had the lowest $p$-value $\left(4.70 \times 10^{-6}\right)$, a high z-score (4.885), and the highest number of downstream targeted genes ( $n=37$ genes) (Figure 8A). The majority of these genes (32) participated in few canonical pathways-mitochondrial dysfunction; oxidative phosphorylation, protein ubiquitination, mTOR signaling and regulation of elongation by Eif2 and Eif4. These functions clearly confirmed the aforementioned seKws, seGO-terms, KEGG, and IPA pathways observations, indicating that in $\mathrm{MgHI}$ condition, protein translation and oxidative metabolism were inhibited through the repression of ribosomal proteins, ubiquinone oxydoreductases, cyclooxygenases, and proteasome proteins (Figure 8A).

Sirtuin1, appeared very early ( $1 \mathrm{~h} 30 \mathrm{~min}$ ) and showed lasting activation of pURs in $\mathrm{MgSO}_{4}$ treatment based on the regulation of 32 putative downstream genes, mainly 
repressions. An opposite activating pattern was observed $12 \mathrm{~h}$ after HI. Sirtuin 1 did not appear to be a pUR in the MgHI one-color list, but the Sirtuin signaling pathway was a significant pathway extracted from the de novo list (7). These observations indicate that $\mathrm{MgSO}_{4}$ influenced the expression of many genes downstream to Sirtuin1, possibly at the protein level, resulting in a change in $\mathrm{HI}$ induction in pretreated animals (Figure 8B).

Infg was the most significant pUR in $\mathrm{HI}$ conditions at 3 and $12 \mathrm{~h}$ as a potential activation factor $(\mathrm{z}>4.4)$. Although a high $\mathrm{z}$-score was measured in the $\mathrm{MgHI}$ one-color analysis, it did not remain a significant pUR (Figure 9A). A majority $(n=30)$ of the 42 genes downstream of Ifng in $\mathrm{HI}$ at $12 \mathrm{~h}$ were no longer affected in $\mathrm{MgHI}$ conditions. Many other factors involved in inflammation processes showed similar patterns (Table S2E). pUR comparison did not allow to extract a unique target for $\mathrm{MgSO}_{4}$ in lowering the $\mathrm{HI}$ induced inflammation process, but the global tendency allowed us to conclude that $\mathrm{MgSO}_{4}$ prevented inflammatory effects of $\mathrm{HI}$ in the $\mathrm{P} 5$ mouse brain as a possible cause of its neuroprotection effects.

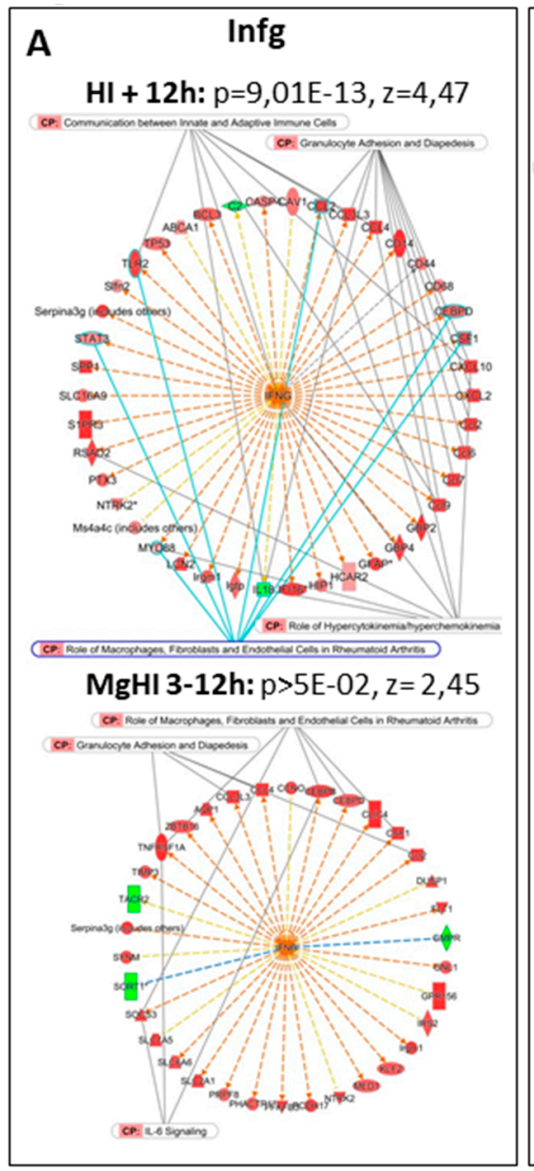

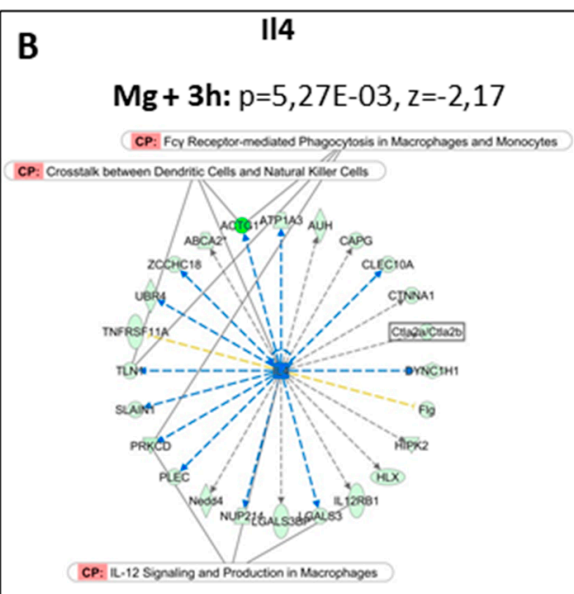

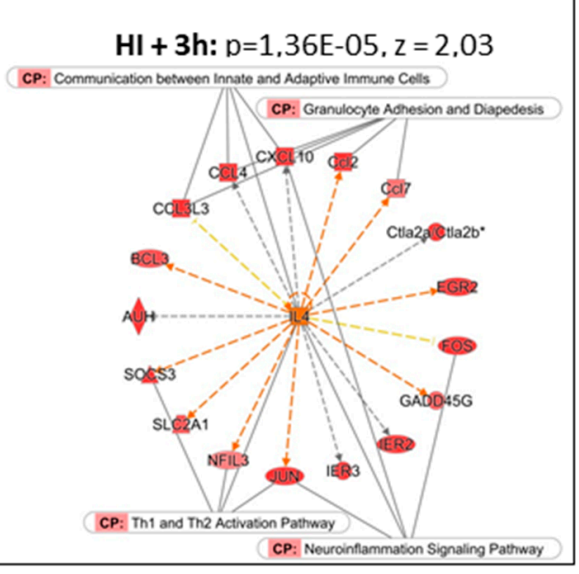

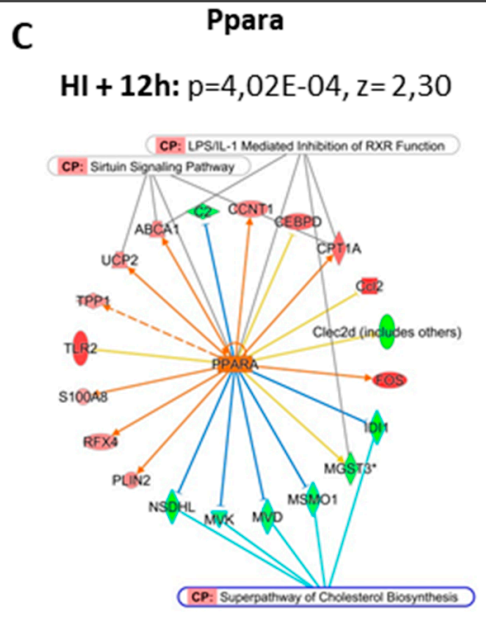

$M g H I+3 h: p=1, z=-1,37$

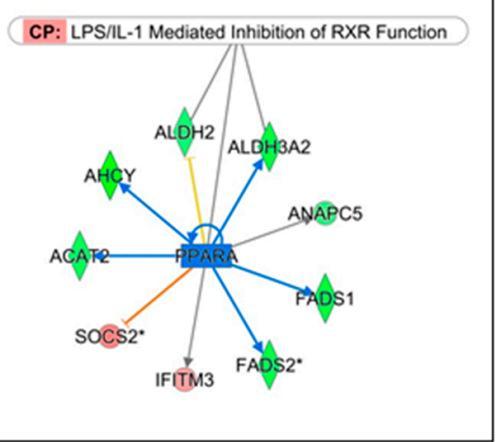

Figure 9. Putative upstream regulators (pURs) of $\mathrm{MgSO}_{4}$ effects on the $\mathrm{HI}$ transcription response. (A) Activation of Ifng appeared to be a significant activated pUR $\left(p=9.01 \times 10^{-13}, \mathrm{z}=4.472\right) 12 \mathrm{~h}$ after HI, putatively activating 42 genes also associated with inflammation and immunity CPs (top panel). In MgHI, it did not remain a significant pUR $\left(p>1 \times 10^{-2}\right.$, $\mathrm{z}=3.111$ ) although it was associated with the activation of 31 genes (bottom panel). Only 7 genes were common to the two conditions. (B) The inhibition of IL4 by $\mathrm{MgSO}_{4}$ in naïve mice identified it as a pUR $(p=\mathrm{z}=-3.561)$ associated with the repression of 24 genes, of which several were also recorded as part of CPs (top panel). IL4 activation in the HI response makes it a pUR of inflammation activating 17 genes involved in this function (lower panel). IPA ${ }^{\circledR}$ did not consider IL4 a pUR in MgHI groups. (C) Activation of Ppara $\left(p=4.02 \times 10^{-4}, \mathrm{z}=2.302\right)$ in HI $12 \mathrm{~h}$ after insult showed it to be a pUR in the $\mathrm{HI}$ response in Ctrl mice, as well as the possible upstream negative regulator of cholesterol biosynthesis repressor (highlighted in blue, top panel). $\mathrm{MgSO}_{4}$ pretreatment reversed activation of Ppara with pUR inhibitory activity on function, at least at a short time post insult (bottom panel). *; multiple identifiers (probes) in data list. 
Il4 appeared to be an inducer in $\mathrm{HI}(\mathrm{z}=2.0333 \mathrm{~h}$ after $\mathrm{HI})$, and a possible inhibitory pUR of $\mathrm{MgSO}_{4}$ effects $(\mathrm{z}<-2$ from 3 to $12 \mathrm{~h}$ ), but did not reach significance in MgHI conditions (11 of 16 genes downstream to Il4 affected in HI were unaffected in MgHI) (Figure 9B). The Il4 gene did not show transcription regulation in any experimental.

Ppara appeared to be a lowly significant activating pUR in HI at $12 \mathrm{~h}\left(p=4.02 \times 10^{-4}\right.$, $\mathrm{z}=2.302)$, and did not appeared significant in MgHI at $3 \mathrm{~h}\left(p>5 \times 10^{-2}, \mathrm{z}=-1.938\right)$ (Figure 9C). It retained our attention however, as it may be a hub for the inhibition of the cholesterol biosynthesis pathway in $\mathrm{HI}$ at $12 \mathrm{~h}$. (Figure 9C). Two of these 5 genes (Idi1 and Msmo1) were activated in $\mathrm{MgHI}$, while $\mathrm{Mvd}, \mathrm{Mvk}$, and Nsdhl were unaffected. These divergent effects preclude $\mathrm{MgSO}_{4}$ effect on Ppara.

\subsubsection{HI Effects Insensitive to $\mathrm{MgSO}_{4}$}

seGO-term extraction from List $\mathrm{C}$ enabled us to evaluate the putative effects of $\mathrm{HI}$ that were insensitive to $\mathrm{MgSO}_{4}$ pretreatment. Gene inductions, predominant in $\mathrm{HI}$, are related to transcription by RNA-polymerase-II, inflammation and angiogenesis as previously described [29]. Reciprocally, the repression of genes encoding cholesterol biosynthesis enzymes was observed (Idi1, Mvk and Mvd, Msmo1 and Nsdhl), although the significance threshold was not reached. A minority of genes affected by $\mathrm{HI}$ in list (3) appeared to be unaffected in List C - 166/499 inductions (33\%) and 66/224 repressions (29\%). As far as gene ontology is valid for partial lists, seGO-terms related to inflammation were absent in $\mathrm{C}$, with the exception of the response to cytokine and monocyte chemotaxis. Otherwise the seGO-terms related to RNA polymerase II identified from List (3) remained in List C (Table S8).

\section{Discussion}

Neonate mice at P5 show forebrain development and sensitivity to insults which was somewhat representative of human brain development and vulnerability around 2832 GWs, and may be used as experimental surrogates [24,35-37]. However, one must keep in mind that putative $\mathrm{MgSO}_{4}$ neuroprotection in humans also results from activities in the mother, at the placental level, and that the purpose of the present study was restricted to $\mathrm{MgSO}_{4}$ effects on the neonate. Acute single $\mathrm{MgSO}_{4} 600-\mathrm{mg} / \mathrm{kg}$ administration in $\mathrm{P} 5$ mice evoked transient transcription effects, mainly repressions, for a short period culminating $6 \mathrm{~h}$ after injection. The gene ontology and pathways extraction pointed out the effects of $\mathrm{MgSO}_{4}$ on synapses and brain development (Figure 10). The administration of $600-\mathrm{mg} / \mathrm{kg}$ $\mathrm{MgSO}_{4}$ in $\mathrm{P} 5$ mice induces a transient peak concentration $30 \mathrm{~min}$ after administration. Blood concentration was $1.5 \mathrm{mM}$ after $6 \mathrm{~h}$, a concentration detected for longer periods in preterm born from mother having received $4-6 \mathrm{~g}$ bolus plus $1-2 \mathrm{~g} / \mathrm{h}$ maintenance $[18,40]$. In mice pups, the concentration returned to basal level within $24 \mathrm{~h}$, while it often remained above $1 \mathrm{mM}$ in human, leading us to consider the $600-\mathrm{mg} / \mathrm{kg}$ bolus as a low $\mathrm{MgSO}_{4}$ dose [17,40]. Under these conditions $\mathrm{MgSO}_{4}$ did not induce apoptosis [28].

Concerning the transcription effects of $\mathrm{MgSO}_{4}$ alone, one could note the convergence toward synapse differentiation and function in either, seKws, seGO-terms and pathways identified in Mg groups. Two highly significant and durable pURs were identified as potential targets of $\mathrm{Mg}^{2+}: \mathrm{Mnk} 1$ and Frm-1. These two proteins have activity in protein translation. Mnk1 requires $\mathrm{Mg}^{2+}$ binding on a specific binding loop to achieve maximum activity [41]. Mnk1 inhibition as a pUR nevertheless appeared to be the most significant and durable putative target of $\mathrm{MgSO}_{4}$, inducing the actual repression of many downstream genes. Fmr1 transcription was not affected in any experimental group but the synaptic functional regulator Fmr-1 also appeared to be an activating pUR site for $\mathrm{MgSO}_{4}$, although the literature does not report an $\mathrm{Mg}^{2+}$ cation link to protein activity. Functional relationships between (i) $\mathrm{MgSO}_{4}$ effects through Mnk1 and Fmr-1, and (ii) subsequent synaptogenesis appear to be reliably supported by our finding, but the modes of action remained undetermined. As a polyribosome-associated mRNA-binding protein, Fmr-1 
indicates a $\mathrm{Mg}^{2+}$ putative action on protein translation that appeared more clearly in the MgHI group.

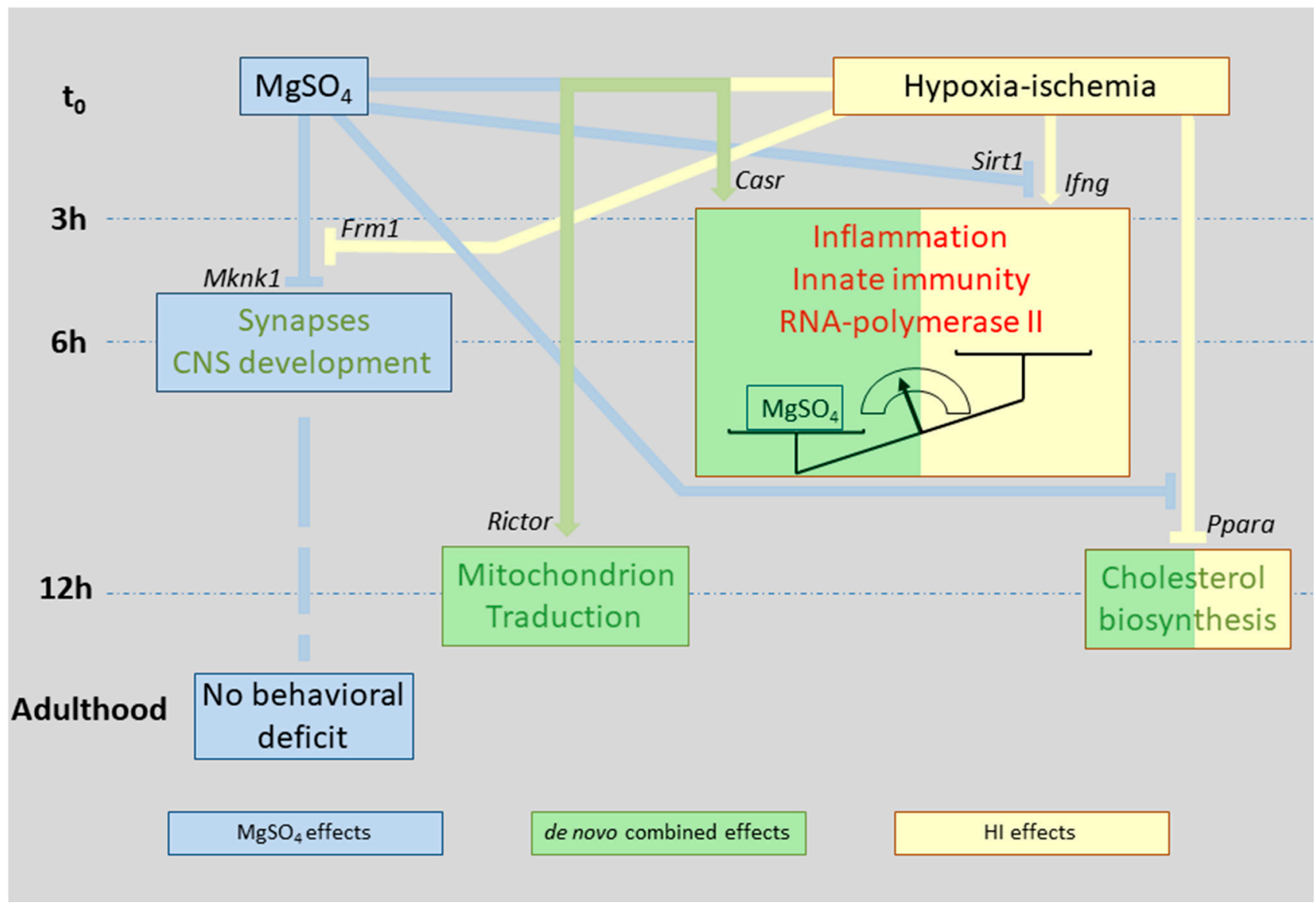

Figure 10. Simplified schematic effects of $\mathrm{MgSO}_{4}$ (in blue) and $\mathrm{HI}$ (in yellow) applied separately or in association (in green) with transcription in 5-day-old mouse brain hemispheres. Genes identified as putative upstream regulators of main effects are indicated. Red or green lettering indicate function activations and inhibitions, respectively.

Although transcription effects were very transient, it is possible that this interference with such a crucial development process could have long-term consequences, as reported for several pharmacological agents eventually used in neonatal pediatrics (corticoids anesthetics, NSAIDs), or in animal models (MK-801, ketamine) [42-46]. We assessed several behavioral responses in adults exposed to neuroprotective dose of $\mathrm{MgSO}_{4}$ compared with drugs with known effects at P5. The battery of tests was chosen to mitigate the simple spontaneous response to a new environment and more integrated drug- or congener-evoked responses. This battery of tests in fact allowed for the discrimination of non-convergent behavioral parameters, since positive controls injected with MK-801 or ketamine had separate sex- and test-specific effects. $\mathrm{MgSO}_{4}$ acute neonatal treatment did not modify adult behavior in these tests. Although it is difficult, from a statistical point of view, to demonstrate an absence of effect, these data argue against a putative deleterious effect of $\mathrm{MgSO}_{4}$ at a neuroprotective dose, in particular through its interaction with the NMDA-type glutamate receptor. Previous studies have reported that high doses of $\mathrm{MgSO}_{4}$ may impair vascular development, then nervous parenchyma [8]. The use of repeated $\mathrm{MgSO}_{4}$ administration was performed to assess this possibility, in conditions designed to mimic the prolonged administration that eventually occurs in pregnant women at risk of preterm delivery. In this respect, it is interesting to note the absence of lasting effects of repeated $\mathrm{MgSO}_{4}$.

The present data on $\mathrm{MgSO}_{4}$ effects showed transient transcription modulation apparently devoid of delayed deleterious effects and putatively capable of exerting brain 
protection. The study of $\mathrm{MgSO}_{4}$ in neonate mice confirmed its harmlessness, which has also been largely reported in humans. This does not preclude other effects of $\mathrm{MgSO}_{4}$, i.e., on the highly vulnerable white matter around 30 GWs (MagNUM) study; [47]. In the MagNUM study, white matter analysis by means of magnetic resonance imaging revealed the induction by $\mathrm{MgSO}_{4}$ of microstructure development, a finding coherent with the present observation of $\mathrm{MgSO}_{4}$ transcription inductions/repressions orthologous to spontaneous development in 264 genes.

$\mathrm{MgSO}_{4}$ is not only safe, it is also a potent prevention agent of motor, behavior, and cognitive deficiencies in preterm subjects [6,48], although its mode of action is not fully understood.

Another concern about the use of $\mathrm{MgSO}_{4}$ as prophylactic a neuroprotection in fragile populations was the frequent statement that it acts as an NMDA channel blocker [49]. This belief was often based on a very dated description of NMDA function and also to the fact that $\mathrm{MgSO}_{4}$ was neuroprotective in NMDA mediated neurotoxicity $[18,35,50]$. This possibility is frightening owing to the very deleterious effects in the developing brain of NMDA blockers such as MK-801 in animals [43], and with the relationship of NMDA hypoactivity or genetic defects with schizophrenia [51]. Administration of $\mathrm{Mg}^{2+}$ reduced the release of $\mathrm{Mg}^{2+}$ from NMDA channel, but it does not act as an antagonist. Mg block lifting is dependent on depolarized membrane potential but not on glutamate and glycine (Dserine) binding [52]. Under depolarization $\mathrm{Mg}^{2+}$ loses intra-channel binding high affinity, making it unlikely that overload would reduce NMDA excessive activation. Moreover, the expression of NMDA-R subunits in 30-GW human brains have shown $\mathrm{Mg}^{2+}$ blocking sensitivity [53]. In vitro studies showed that in different neuron populations, low doses of glutamate-induced pre-conditioning toward high glutamate excitotoxicity can be mimicked using $\mathrm{Mg}^{2+}$ supplementation, indicating a clearly more complex effect of magnesium on NMDA receptors than channel blocking [52]. At the transcription level, $\mathrm{MgSO}_{4}$ repressed Grin1 and Grin3a in Ctrl and reversed Grin $2 b$ induction after HI (Tables S1 and S2). These effects together with the reduction by $\mathrm{Mg}^{2+}$ of glutamate release would underlie its antiglutamatergic toxicity more likely than NMDA blockade [54]. The present behavioral observations showed that $\mathrm{MgSO}_{4}$ effects did not mimic the effect of the NMDA specific blocker MK-801. In addition, transcriptome IPA ${ }^{\circledR}$ analysis never proposed genes coding NMDA receptor subunits as pURs, even at low significance levels before filtering. The statistical proof of an absence of effect is always a difficult challenge. Thus, a demonstration that $\mathrm{MgSO}_{4}$ does not affect NMDA transmission in the $30-\mathrm{GW}$ fetus is probably elusive; however $\mathrm{MgSO}_{4}$ may be considered a safe prevention tool in the neonatal context, and is very likely devoid of NMDA-interfering side effects. On the contrary, the incidental observation of ketamine's interference with basal activity and social behavior renews the question of its use (or abuse) in the newborn [55]. The clearly distinct effects of ketamine compared to MK-801 ruled out ketamine's interaction with NMDA in these effects and lead us to consider ketamine for broader potential neurotoxic effects.

A major concern in very preterm care is the high incidence of brain hemorrhages. Meta-analyses of prophylactic antenatal $\mathrm{MgSO}_{4}$ exposure did not conclude that it led to intraventricular hemorrhage (IVH) prevention, although tendencies were reported [6]. Relatedly, $\mathrm{MgSO}_{4}$ slightly reduced cerebellar hemorrhage [1]. In an original model of preterm hemorrhage, we observed a $20 \%$ reduction of hemorrhage occurrence after $\mathrm{MgSO}_{4}$ $600 \mathrm{mg} / \mathrm{kg}$ administration in P5 mice (not shown), in line with therapeutic trends $[1,56]$. As hemorrhages largely depend on brain vessel immaturity in humans, it appears likely that the deleterious vascular effects of $\mathrm{MgSO}_{4}$ reported for high dosages did not occur at neuroprotection low doses [8,57].

Neuroprotection in fetuses using low $\mathrm{MgSO}_{4}$ doses given to women at risk of preterm delivery before completed $33 \mathrm{GWs}$ is now recognized and approved as the gold standard in many countries $[4,58]$. Its action reported in preterm exposed to $\mathrm{MgSO}_{4}$ in the last in utero periods showed respiratory and hemodynamic stabilization, but $\mathrm{MgSO}_{4}$ also showed direct neuroprotection of the neural tissue. Combined transcriptomics and metabolomics 
approaches showed a type of $\mathrm{MgSO}_{4}$ preconditioning effect on mitochondria, resulting in the sparing of high-energy phosphate and the reduction of succinate, involved in ROS production and inflammation [33].

Moving to $\mathrm{MgSO}_{4}{ }^{\prime}$ s prevention of $\mathrm{HI}$ effects in the neonate mouse, a remarkable observation was that the combination of $\mathrm{MgSO}_{4}$ plus $\mathrm{HI}$ did not elicit a summation of the effects observed in separate conditions. $\mathrm{MgSO}_{4}$ alone had its maximum transcription effects after $6 \mathrm{~h}$ although it affected $\mathrm{HI}$ responses as early as $3 \mathrm{~h}$ after insult, reorientating the responses in an original direction. This effect of $\mathrm{Mg}^{2+}$ was likely the result of nontranscriptional effects; i.e., at protein activity levels, before $\mathrm{Mg}^{2+}$ induced transcription modulation occurred (Figure 6). Although $\mathrm{HI}$ responses largely differed in terms of identity of the genes affected in Ctrl or in $\mathrm{MgSO}_{4}$-treated animals, they converged toward the same functions; inflammation, innate immunity and mRNA transcription by RNA-polymerase II complex. The reduced amplitude of effects was, however, in line with expected antiinflammatory $\mathrm{MgSO}_{4}$ effects [25]. Anti-inflammatory effects of $\mathrm{MgSO}_{4}$ at the transcription level in an HI context toward Ccl2 Cxcl1, Ccl3, and Csf1 coincided with the reported effects at the protein level on early inflammation response factors (MCP-1,GRO/KC,MIP$1 \alpha$ and M-CSF) described in rat [33]. Transcriptomics allowed us to extend the $\mathrm{MgSO}_{4}$ action field to Tlr3,4,9, Il1 $\alpha, \beta, \mathrm{Tnf}, \mathrm{Nf} \kappa \mathrm{B}$, and Ifng-mediated pathways. Relatedly, the absence of transcription effects on Il4 and Il10 transcription was in accordance with the observations at the protein level. Ifng appeared as a pUR in HI at the highest significance but did not appear in $\mathrm{MgHI}$, together with many pro-inflammation genes (Stat3, Tlr4, $\mathrm{Ccr} 2, \mathrm{C} x 3 \mathrm{cl} 1$, Chuk, $\mathrm{Nf}_{\mathrm{k}} b, \mathrm{Ccl} 2$, Stat1, and Saa1). Among these genes, only Ccl2 and Stat1 were affected at the transcription level, also indicating that $\mathrm{MgSO}_{4}$ essentially prevented $\mathrm{HI}$-induced inflammation at post-transcription levels. Ifng also had a putative impact on innate immune cells since most putative downstream effectors were related to chemokine and, macrophages-immune cell communication pathways (Figure 9A).

In preterm subjects, increased Il-4 levels in the cerebrospinal fluid contributed to a cytokinic neuro-inflammatory profile [59]. In HI mice, Il-4 appeared as a pUR, suggesting an early regulatory function on the inflammation process. In Mg groups it showed a tendency to aggregate Il-4 putative downstream targets, but no clear inhibition by $\mathrm{MgSO}_{4}$ of $\mathrm{HI}$ effects indicate that Il-4 was a target of Mg. Il-4's anti-inflammation function is in part due to its favoring the M2a macrophage/microglial phenotype in neonates [60,61]. In fact, an Mg induction of M2a phenotype has been reported as enhancing Il4, Il10, Bmp2, and Vegf expression [62]. In our hands, $\mathrm{MgSO}_{4}$ likely had post-transcription interaction with Il-4, but examination of Il-4 downstream microglial markers of repair (M2A) or the immuno-modulatory (M2B) phenotypes did not indicate convergent $\mathrm{Mg}$ effects [61]. Therefore, $\mathrm{Mg}^{2+}$ s putative anti-inflammatory effects were rather due to the inhibition of the pro-inflammatory pathways than by inducing an anti-inflammatory differentiation of microglia.

De novo effects were detected in $\mathrm{MgHI}$, with high $p$-values for mitochondria and to a lesser extent for ribosome-related indexes. Magnesium reduced the transcription of genes involved in energy metabolism, protein translation, and protein degradation through ubiquitination. mTORC2 (coded by Rictor) and Sirt1 should be considered inhibitory hubs for oxidative phosphorylation and protein translation and degradation in $\mathrm{MgHI}$ mice. Rictor codes $\mathrm{mTORC} 2$, the rapamycine insensitive companion of $\mathrm{mTOR}$ which integrates many cell-survival-linked functions and requires $\mathrm{Mg}^{2+}$ for its activation [63]. $\mathrm{MgSO}_{4}$ previous to the Rice and Vannucci procedure in rats at P7 showed preserved mitochondrial functions after $\mathrm{HI}$ suggesting a pre-conditioning mechanism [33]. In our hands, putative mTORC2 $\mathrm{MgSO}_{4}$ activation may have resulted in the repression of 33 genes and 1 induction, of which 11 genes were coding factors of mitochondrion membrane respiration chain complex 1. These genes were distinct from those identified in rats at P7, although at a different time point, but the observations converge toward mitochondrial targeting by $\mathrm{MgSO}_{4}$ [33]. In addition, mTORC2 appeared to be a potential downstream hub by which $\mathrm{Mg}^{2+}$ affects protein translation. The repression of 12 genes coding ribosomal proteins 
putatively occurred downstream of mTORC2 activation, half of which were coding proteins further localized at the synapse (Rpsa, Rps1, Rps15, Rps18, Rp17, Rp110). Of note, none of the genes coding these proteins was affected in $\mathrm{Mg}$ groups in which synaptic tropism of $\mathrm{Mg}$ effects was noted, once again indicating a de novo mechanism recruited in $\mathrm{MgHI}$.

Many $\mathrm{MgSO}_{4}$ pretreatment effects could be detected or suspected in the absence of up-coming HI, such as inhibitory effects on signaling pathways dependent on GPCR, a well-known target of $\mathrm{Mg}^{2+}$ in terms of membrane trafficking, and transduction effects. The rapid diffusion of the divalent cation and interaction at these sites support the view of rapid $\mathrm{MgSO}_{4}$ interference with $\mathrm{HI}$, and sustain the findings of upstream regulators as putative Mg targets, even when unaffected at their own transcription level.

\section{Materials and Methods}

\subsection{Animals}

National marine research Institute (NMRI) mice, purchased from Janvier Labs (Le Genest-Saint-Isle France), were housed sex-separated at a controlled temperature $\left(21^{\circ} \mathrm{C}\right)$ with access to food and water ad libitum with a 12-h light/dark cycle. Reproduction was performed locally by putting females in male cages for one night to cause birth at definite days. The day of birth was noted as day 1 . All nursing and experimental procedures were performed according to the recommendations of the European Communities council directives (2010/63/UE) and French national legislation. Protocols received the agreement of the French Ministry of Higher Education and Research (\#01680.02/2014) and were performed by authorized experimenters with efforts to minimize animal numbers and suffering. Animal numbers are given in Table S3.

Transcriptome studies were carried out in four groups of NMRI mice aged 5 days (P5).

The Control group (Ctrl) underwent no intervention.

The $\mathrm{Mg}$ group of animals received an intra-peritoneal $\mathrm{MgSO}_{4}$ bolus injection $(3.33 \mu \mathrm{L} / \mathrm{g})$ at $600 \mathrm{mg} / \mathrm{kg}$ of body weight as previously reported [28]. Brains were collected at 5 time points- $1.5 \mathrm{~h}, 3 \mathrm{~h}, 6 \mathrm{~h}, 12 \mathrm{~h}$, and $24 \mathrm{~h}$.

The HI group in which animals were exposed to hypoxia-ischemia as previously described [28]. Briefly, isoflurane anesthetized pups had a right carotid ligature, and were returned to the mother. Then, after 60-120 min of recovery from anesthesia and surgery, the pups were exposed to $8 \% \mathrm{O}_{2}$ for $40 \mathrm{~min}$ in a humidified and thermostatic chamber at $36{ }^{\circ} \mathrm{C}[28,37]$. The end of hypoxia was considered $\mathrm{t}_{0}$ for the 3-h and 12 -h post HI periods.

The $\mathrm{MgHI}$ group of animals received $\mathrm{MgSO}_{4}$ pretreatment one hour before being exposed to hypoxia-ischemia [28].

Behavioral studies were performed in a total of 204 mice treated at P5 by a single injection of saline buffer (PBS), $\mathrm{MgSO}_{4}(600 \mathrm{mg} / \mathrm{kg})$, or positive control pharmacological agents-MK-801 (1 mg/ $\mathrm{kg})$ or ketamine $(40 \mathrm{mg} / \mathrm{kg})$, known to induce long-term effects in the behavior paradigm evaluated (details in Supplementary file). Repeated daily injections of PBS or $\mathrm{MgSO}_{4}(600 \mathrm{mg} / \mathrm{kg})$ from day 5 to day 9 were performed in separate groups. Each parameter is considered as mean \pm standard error to the mean.

\subsection{RNA Sample Preparation and Microarray Hybridization}

Brains were quickly removed under isoflurane anesthesia, sectioned on medial line and ipsilateral hemispheres and were immediately frozen in liquid nitrogen. Pool samples for the microarray study were made with $5 \mu \mathrm{g}$ of RNA extracted from 6 ipsilateral hemispheres of sex-matched injured or control mice in the different experimental groups and time points. Mice pups at each time point were taken from at least two different litters. A total of 288 pups were used for the transcriptome study (details in supplementary file).

RNA extraction was performed in individual hemispheres. Brain tissues were thawed in $350 \mu \mathrm{L}$ of tissue lyser ${ }^{\circledR}$ (Qiagen, Courtaboeuf, France) and homogenized using ceramic beads (1.4 mm Ozyme, Montigny le Bretonneaux) for $20 \mathrm{~s}$ at $50 \mathrm{~Hz}$. Total RNA extraction was done using the Nucleospin RNA plus $\mathrm{kit}^{\circledR}$ according to the manufacturer's recommendations (Macherey-Nagel, Hoerdt, France, www.servilab.fr (accessed on 15 April 2021)) and 
stored at $-80^{\circ} \mathrm{C}$ until use. The quality and quantity of isolated RNAs were assessed using the 2100 Bioanalyzer (Agilent Technologies, Santa Clara, CA, USA) and the Nanodrop (Thermo Scientific, Wilmington, NC, USA). Labeled cRNA was synthesized from $100 \mathrm{ng}$ total RNA using the Quick Amp Labeling Kit according to the manufacturer's recommendations (Agilent Technologies, Les Ulis, France). A total of $825 \mathrm{ng}$ of labeled cRNA (Cy3 for control samples and Cy5 for test samples) was co-hybridized for $17 \mathrm{~h}$ at $65{ }^{\circ} \mathrm{C}$ on Whole Mouse Genome Oligo $4 \times 44 \mathrm{~K}$ microarrays (G4845A, Agilent Technologies, Les Ulis, France). Raw hybridization data were extracted using an Agilent DNA microarray scanner G2565CA (Agilent Technologies), and normalized (using LOWESS method) by Feature extraction software (v.10.5.1.1), then were transferred to Genespring ${ }^{\circledR}$ (GX v.14.9.1 software, Agilent Technologies, Santa Clara, CA, USA) for data processing and data mining.

Hybridization data were filtered on spot quality (uniformity) detection level (above 2 -fold background in at least 2 samples out of three in one-color analyses) and statistically selected using GeneSpring ${ }^{\circledR}$ (GX 12.6 software, Agilent Technologies, Les Ulis, France), as previously described in detail $[29,64]$. Only probes referring to validated genes (Official Gene Symbol) were taken into account. Probes for cRIKEN sequences were excluded from analysis. In the case of multiple probes for one gene, the probe exhibiting the highest fold change was used for subsequent analyses.

Raw data were deposited in the NCBI Gene-Expression-Omnibus repository (GSE 144455: https: / / www.ncbi.nlm.nih.gov/geo/query/acc.cgi?acc=GSE144455 (accessed on 24 January 2020))

\subsection{Strategy of Transcriptomic Analysis}

The study was designed to extract the effects of $\mathrm{MgSO}_{4}$ alone (List A) and $\mathrm{MgSO}_{4}$ interference with $\mathrm{HI}$ effects (List B) at the transcriptional level. Transcription responses were measured using a two-color strategy in three independent experiments. The signal from any probe was recorded when the $p$-value in the t-test against 0 was below $5 \times 10^{-2}$. The extraction of regulated probes was performed at each time point separately (Figure 1).

- Experiment 1 (Mg vs. Ctrl): The effects of $\mathrm{MgSO}_{4}(600 \mathrm{mg} / \mathrm{kg}$ bolus at P5) were evaluated through comparison with control brains (Ctrl). The effects (inductions and repressions) were investigated at 5 time points ( $1 \mathrm{~h} 30 \mathrm{~min}, 3 \mathrm{~h}, 6 \mathrm{~h}, 12 \mathrm{~h}$, and $24 \mathrm{~h}$ ), in three independent samples per time point post-injection.

- $\quad$ Experiment 2 (MgHI vs. HI): The effect of $\mathrm{MgSO}_{4}$ pretreatment on the transcription response to $\mathrm{HI}$ was evaluated by comparison with HI-exposed brains at 2 time points after HI. The choice of $3 \mathrm{~h}$ and $12 \mathrm{~h}$ post-insult time points was based on previous data, in order to detect early onset and peak responses in P5 brains [29].

- $\quad$ Experiment 3 (HI vs. Ctrl): The effect of HI was evaluated by comparison to control brains at $3 \mathrm{~h}$ and $12 \mathrm{~h}$ time points to ensure reproducibility with the previous study and to provide reference effects of HI at P5 [29].

In all three experiments, the two-color analysis identified significant inductions and repressions. Thus, the effects on genes affected both in (1) and (2), or in (2) and (3) must take into account the direction of variation that might differ among common entities (Figure 2).

Comparisons of expression levels on one fluorochrome can also be extracted from separated arrays after normalization using the Genespring ${ }^{\circledR}$ one-color protocol and allow broader comparisons of conditions. One-color analyses were performed to compare expression levels in the $\mathrm{Mg}$ group to (i) respective levels in the $\mathrm{MgHI}$ group, in order to exclude $\mathrm{MgSO}_{4}$ pretreatment effects that did not interfere with $\mathrm{HI}$, and (ii) $\mathrm{MgHI}$ to Ctrl, as detailed below.

- List A, extracted from the two-color analysis of experiment 1 , described the transcription effects of $\mathrm{MgSO}_{4}$ single injection. The effects of $\mathrm{MgSO}_{4}$ were evaluated at 5 time points. All entities exhibiting either mean change $\geq 2$ fold and/or $p$-values $\leq 0.05$ $t$ test against 0 , according to Benjamini-Hochberg correction were selected at each time point in both directions and recorded in List A. Few genes showed induction and repression of separate probes. This was due to biphasic regulation ( 1 item) or 
detection of variations on separate probes ( 8 items). These ambiguous items were placed in induced or repressed gene lists for further analyses.

$\circ \quad$ List $\mathrm{A}_{1}$ grouped the fraction of List $\mathrm{A}$ of $\mathrm{MgSO}_{4}$ effects observed in the same direction in the two-color protocol in both $\mathrm{Ctrl}$ and $\mathrm{HI}$ mice, indicating $\mathrm{HI}-$ evoked transcription responses that were unaffected by $\mathrm{MgSO}_{4}$ (4) in Figure 2). The effects observed at least at one time point, in any sense of variation, at 3 and $12 \mathrm{~h}$ were merged in order to be handled as $\mathrm{Mg}$ or $\mathrm{MgHI}$ responses.

- $\quad$ List $\mathrm{B}$ reports the effects of $\mathrm{MgSO}_{4}$ pretreatment on transcription responses to $\mathrm{HI}$. It was obtained by concatenation of three sub-lists $\left(\mathrm{B}_{1}, \mathrm{~B}_{2}\right.$, and $\left.\mathrm{B}_{3}\right)$ describing three classes of effects of $\mathrm{MgSO}_{4}$ : (i) the effects of $\mathrm{HI}$ revealed after $\mathrm{MgSO}_{4}$ exposure (List $\mathrm{B}_{1}$ ), (ii) the reversion by $\mathrm{MgSO}_{4}$ of $\mathrm{HI}$ transcription effects (List $\mathrm{B}_{2}$ ), and (iii) the amplification by $\mathrm{MgSO}_{4}$ pretreatment of $\mathrm{HI}$ transcription effects (List $\mathrm{B}_{3}$ ). The elaboration of these lists required crossed comparisons of two-color and one-color analyses corrections and the subtraction of genes in List $A_{1}$ (Figure 2).

$\circ \quad$ List $\mathrm{B}_{1}$ (concatenation of (5) + (6) + (7)-(4)-(11)) contains the genes affected after $\mathrm{HI}$-exposed $\mathrm{MgSO}_{4}$-pretreated animals in (2) but not after $\mathrm{HI}$ in Ctrl animals in two-color analyses in (3) (5) in Figure 2), plus genes exhibiting opposite effects in (1) and (2) (6) in Figure 2). $B_{1}$ was supplemented by genes exhibiting significant $t$ test differences in one-color analysis between Ctrl values (in (1) and (3) and $\mathrm{MgHI}$ values in (2) (7) in Figure 2). The later series could reveal genes unaffected by $\mathrm{HI}$ (in (3)). Finally, unchanged $\mathrm{MgSO}_{4}$ and $\mathrm{HI}$ effects in combined conditions $\left(\mathrm{A}_{1}\right.$ and (11) $)$ were subtracted.

$\circ \quad$ List $\mathrm{B}_{2}$ (concatenation of (8) + (9)-(4)) contains the genes affected in opposite senses by $\mathrm{HI}$ in Ctrl or in $\mathrm{MgSO}_{4}$ pretreated animals in two-color analysis (8) in Figure 2), plus the genes exhibiting no difference in one-color analysis between Ctrl and $\mathrm{MgHI}$ (9) in Figure 2), minus $\mathrm{A}_{1}$ (4)).

- List $\mathrm{B}_{3}$ (concatenation of (10) - (4)) contains the genes affected by $\mathrm{HI}$ in the same sense after $\mathrm{HI}$ in Ctrl or in $\mathrm{MgSO}_{4}$ pretreated animals (10 in Figure 2) minus $\mathrm{A}_{1}$ (4)).

- $\quad$ List $C$ contained genes exhibiting transcription regulation in the same sense in $\mathrm{MgSO}_{4}$ treated or non-treated mice in (3) and (7) ((11) in Figure 2) and represented genes affected by $\mathrm{HI}$ but not affected by $\mathrm{MgSO}_{4}$ pretreatment.

\subsection{Data Mining}

Gene lists A and B, generated as detailed in Figure 2 were submitted to DAVID ${ }^{\circledR}$ (v 6.8) software $[65,66]$. Enrichment of seKws, seGO-terms, on biological processes (GOTERM_BP_ALL; BP), cell components (GOTERM_CC_ALL; CC) and molecular functions (GOTERM_MF_ALL; MF), and seKpaths were researched using DAVID ${ }^{\circledR}$ software. Keywords and GO-terms enrichment was extracted on the 1411 genes of List A, and the 1958 genes of List $B$ filtered on gene number $(\mathrm{N}) \geq 10$, at the Bonferroni $p$-value threshold $<1 \times 10^{-4}$, or coincidence of $p$-value according to EASE $<1 \times 10^{-4}$ with FE $>2$ [67]. Clustering of seGO-terms was performed using the online REVIGO software (http: / / revigo.irb.hr/ (accessed on 15 April 2021)) to discard redundancy (dispensability <0.7) [68]. Filtering conditions to extract seKPaths, were set at $\mathrm{N} \geq 10$ entities, Bonferroni $p$-value threshold $<5 \times 10^{-2}$ and FDR $<10 \%$ for each item.

Pathway investigation was completed by the literature-based Ingenuity Pathway Analysis $\left(\mathrm{IPA}^{\circledR}\right)$. IPA ${ }^{\circledR}$ used human gene nomenclatures (showing slight differences with mice). IPA analysis provided a z-score, indicating the sense of regulation (activation or inhibition) of significantly enriched pathways (seIPaths). We recorded the canonical pathways with $\mathrm{N} \geq 10$ and right-tailed Fisher's Exact Test $p$-values $<0.01$ and I z-score | $>2$, at least at a one-time point after $\mathrm{HI}$ or $\mathrm{MgSO}_{4}$ treatment. Pathway list were compared and classified using hierarchical clustering based on $p$-value and z-scores (selection set at $p$-values $<1 \times 10^{-4}$ and $\mid \mathrm{z}$-score $\mid>2$ ), using $\mathrm{IPA}^{\circledR}$, on the basis of comparison of $\mathrm{MgSO}_{4}$ 
effects at 4 different time points; $\mathrm{HI}$ effects at $3 \mathrm{~h}$ and $12 \mathrm{~h}$ and $\mathrm{MgHI}$ vs. HI effects at $3 \mathrm{~h}$ and $12 \mathrm{~h}$, in lists determined by the Genespring ${ }^{\circledR}$ normalized Cy ratio. IPA analysis did not indicate an FDR.

Putative upstream regulators (pUR) identification was performed by IPA ${ }^{\circledR}$ comparisons selected based on right-tailed Fisher's Exact Test $p$-values $p$ value $<1 \times 10^{-4}$ and $\mid z$-score $\mid \geq 2$. List handling and presentation was undertaken using Microsoft Excel ${ }^{\circledR}$ (2016 MSO 16.0.4849.1000). Comparisons of induction/repression distributions in enriched terms were performed using Fisher' exact test using GraphPad Prism6 ${ }^{\circledR}$ software (La Jolla, CA, USA).

Interference of $\mathrm{MgSO}_{4}$ injection with development in control and in HI-exposed mice has been explored using previously described spontaneous variations of expressions before and after P5 (details in Supplementary Materials) [37], deposited in the NCBI Gene Expression Omnibus; GSE144456).

A complement experiment of two-color analysis of $\mathrm{MgHI}$ and $\mathrm{Ctrl}$ on 3 replicates at $3 \mathrm{~h}$ and one at $12 \mathrm{~h}$ after $\mathrm{HI}$ was performed to consolidate one color analysis (Data in Supplementary Materials).

\subsection{Behavioral Studies}

Three different behavioral tests were performed to assess long-term putative effects at adulthood of neonatal treatments. Six experimental groups were studied. Four groups received a single injection at $\mathrm{P} 5$ of saline (PBS), $\mathrm{MgSO}_{4},(600 \mathrm{mg} / \mathrm{kg}), \mathrm{MK}-801(1 \mathrm{mg} / \mathrm{kg})$, or ketamine $(40 \mathrm{mg} / \mathrm{kg})$, and two groups were treated daily for P5 to P9 with PBS or $\mathrm{MgSO}^{4}$. Behavior was tested at adulthood to evaluate spontaneous activity, acute MK-801 $(375 \mu \mathrm{g} / \mathrm{kg})$ evoked activity, and social behavior. Spontaneous activity was assessed in a free-access running wheel in the home cage for 3 days and in an open field for $30 \mathrm{~min}$. In the open field, activity changes induced by acute MK-801 subcutaneous injection were recorded for $150 \mathrm{~min}$ separately [69]. Social interaction with an unknown congener was assessed for $6 \mathrm{~min}$ in a two-compartment device after a 3-min habituation period of the test animal, as previously described [37].

\section{Conclusions}

$\mathrm{MgSO}_{4}$ had a wide spectrum of activities slowing-down transcription, which were largely oriented toward synaptic development in P5 neonatal mice. These effects were transient and did not affect further behavioral activities in grownups. The transcription pattern response to $\mathrm{MgHI}$ appeared very different to the arithmetic summation of separate effects of $\mathrm{MgSO}_{4}$ and $\mathrm{HI}$. Rather, it appeared that $\mathrm{MgSO}_{4}$ priming reoriented $\mathrm{HI}$ response in an original direction, from which neuroprotection may result. Administered before $\mathrm{HI}$, $\mathrm{MgSO}_{4}$ reduced inflammation and innate immune responses. $\mathrm{MgSO}_{4}{ }^{\prime}$ s slowing effects on transcription by RNA-polymerase II or on protein translation by Eif2, 4 may result from the orientation of energy metabolism toward low-energy-cost high phosphate pathways. These effects possibly result from mitochondrial targeting and the reduction of protein translation but not from microglial induction toward regulatory functions.

Supplementary Materials: The following are available online at https:/ /www.mdpi.com/article/10 $.3390 /$ ijms22084253/s1.

Author Contributions: Conceptualization, B.L.D.-L., N.D., C.D., S.M. and P.L.; methodology, C.D. and A.A.; software, C.D., A.A. and P.L.; validation, B.L.D.-L., N.D. and C.D.; formal analysis, C.D. and P.L.; investigation, B.L.D.-L., N.D., C.D., F.J. and A.A.; resources, B.L.D.-L., C.D., A.A. and P.L.; data curation, A.A., C.D. and P.L.; writing-original draft preparation, P.L.; writing-review and editing, S.M. and P.L.; visualization, P.L.; supervision, P.L.; project administration, P.L.; funding acquisition, B.J.G., S.M. and P.L. All authors have read and agreed to the published version of the manuscript.

Funding: This research was funded by INSERM, UMR-1245, Normandie Université Rouen and CPER-FEDER PACT-CBS. 
Institutional Review Board Statement: The study was conducted according to the guidelines of the Declaration of Helsinki, and approved by the French "Ministère de l'Education Nationale de l'Enseignement Supérieur et de la Recherche" (protocol code 01680.02 on 13 October 2014).

Informed Consent Statement: Not applicable.

Data Availability Statement: Data supporting the reported results can be found in the NCBI GeneExpression-Omnibus repository; https: / / www.ncbi.nlm.nih.gov/geo/query / acc.cgi?acc=GSE144 455 (accessed on 24 January 2020)

Acknowledgments: The authors thank honorary Isabelle Leroux-Nicollet for manuscript reviewing.

Conflicts of Interest: The authors declare no conflict of interest. The funders had no role in the design of the study; in the collection, analyses, or interpretation of data; in the writing of the manuscript, or in the decision to publish the results.

\section{References}

1. Gano, D.; Ho, M.L.; Partridge, J.C.; Glass, H.C.; Xu, D.; Barkovich, A.J.; Ferriero, D.M. Antenatal Exposure to Magnesium Sulfate Is Associated with Reduced Cerebellar Hemorrhage in Preterm Newborns. J. Pediatr. 2016, 178, 68-74. [CrossRef] [PubMed]

2. Chollat, C.; Sentilhes, L.; Marret, S. Protection of brain development by antenatal magnesium sulphate for infants born preterm. Dev. Med. Child Neurol. 2019, 61, 25-30. [CrossRef] [PubMed]

3. Oddie, S.; Tuffnell, D.J.; Mcguire, W. Antenatal magnesium sulfate: Neuro-protection for preterm infants. Arch. Dis. Child. Fetal Neonatal Ed. 2015, 100, F553-F557. [CrossRef]

4. Doyle, L.W.; Crowther, C.A.; Middleton, P.; Marret, S.; Rouse, D. Magnesium sulphate for women at risk of preterm birth for neuroprotection of the fetus. Cochrane Database Syst. Rev. 2009. [CrossRef] [PubMed]

5. Pryde, P.G.; Mittendorf, R. Using prophylactic, but not tocolytic, magnesium sulfate to reduce cerebral palsy related to prematurity: What dose, and what about infant mortality? J. Perinat. Med. 2011, 39, 375-378. [CrossRef]

6. Crowther, C.A.; Middleton, P.F.; Voysey, M.; Askie, L.; Duley, L.; Pryde, P.G.; Marret, S.; Doyle, L.W.; for the AMICABLE Group. Assessing the neuroprotective benefits for babies of antenatal magnesium sulphate: An individual participant data meta-analysis. PLoS Med. 2017, 14, e1002398. [CrossRef]

7. De Baaij, J.H.; Hoenderop, J.G.; Bindels, R.J. Magnesium in man: Implications for health and disease. Physiol. Rev. 2015, 95, 1-46. [CrossRef]

8. Mittendorf, R.; Dammann, O.; Lee, K.S. Brain lesions in newborns exposed to high-dose magnesium sulfate during preterm labor. J. Perinatol. 2006, 26, 57-63. [CrossRef] [PubMed]

9. Lecuyer, M.; Rubio, M.; Chollat, C.; Lecointre, M.; Jegou, S.; Leroux, P.; Cleren, C.; Leroux-Nicollet, I.; Marpeau, L.; Vivien, D.; et al. Experimental and clinical evidence of differential effects of magnesium sulfate on neuroprotection and angiogenesis in the fetal brain. Pharmacol. Res. Perspect. 2017, 5, e00315. [CrossRef] [PubMed]

10. Shokry, M.; Elsedfy, G.O.; Bassiouny, M.M.; Anmin, M.; Abozid, H. Effects of antenatal magnesium sulfate therapy on cerebral and systemic hemodynamics in preterm newborns. Acta Obstet. Gynecol. Scand. 2010, 89, 801-806. [CrossRef]

11. Nunes, R.D.; Schutz, F.D.; Traebert, J.L. Association between the use of magnesium sulfate as neuroprotector in prematurity and the neonatal hemodynamic effects. J. Matern. Fetal Neonatal Med. 2018, 31, 1900-1905. [CrossRef] [PubMed]

12. Rantone, T.H.; Gronlund, J.U.; Jalonen, J.O.; Ekblad, U.U.; Kaapa, P.O.; Kero, P.O.; Valimaki, I.A. Comparison of the effects of antenatal magnesium sulphate and ritodrine exposure on circulatory adaptation in preterm infants. Clin. Physiol. Funct. Imaging 2002, 22, 13-17.

13. Govindaswami, B.; Nudelman, M.; Narasimhan, S.R.; Huang, A.; Misra, S.; Urquidez, G.; Kifle, A.; Stemmle, M.; Angell, C.; Patel, R.; et al. Eliminating Risk of Intubation in Very Preterm Infants with Noninvasive Cardiorespiratory Support in the Delivery Room and Neonatal Intensive Care Unit. Biomed. Res. Int. 2019, 2019, 5984305. [CrossRef]

14. Caddell, J.L. Evidence for magnesium deficiency in the pathogenesis of bronchopulmonary dysplasia (BPD). Magnes Res. 1996, 9, 205-216. [PubMed]

15. Dai, L.J.; Ritchie, G.; Kerstan, D.; Kang, H.S.; Cole, D.E.; Quamme, G.A. Magnesium transport in the renal distal convoluted tubule. Physiol. Rev. 2001, 81, 51-84. [CrossRef]

16. Rantonen, T.; Kaapa, P.; Jalonen, J.; Ekblad, U.; Peltola, O.; Valimaki, I.; Kero, P. Antenatal magnesium sulphate exposure is associated with prolonged parathyroid hormone suppression in preterm neonates. Acta Paediatr. 2001, 90, 278-281. [CrossRef]

17. Rigo, J.; Pieltain, C.; Christmann, V.; Bonsante, F.; Moltu, S.J.; Iacobelli, S.; Marret, S. Serum Magnesium Levels in Preterm Infants Are Higher Than Adult Levels: A Systematic Literature Review and Meta-Analysis. Nutrients 2017, 9, 1125. [CrossRef] [PubMed]

18. Daher, I.; Le Dieu-Lugon, B.; Dourmap, N.; Lecuyer, M.; Ramet, L.; Gomila, C.; Ausseil, J.; Marret, S.; Leroux, P.; Roy, V.; et al. Magnesium Sulfate Prevents Neurochemical and Long-Term Behavioral Consequences of Neonatal Excitotoxic Lesions: Comparison Between Male and Female Mice. J. Neuropathol. Exp. Neurol. 2017, 76, 883-897. [CrossRef] 
19. Goytain, A.; Quamme, G.A. Identification and characterization of a novel family of membrane magnesium transporters, MMgT1 and MMgT2. Am. J. Physiol. Cell Physiol. 2008, 294, C495-C502. [CrossRef]

20. Lamhot, V.B.; Khatib, N.; Ginsberg, Y.; Anunu, R.; Richter-Levin, G.; Weiner, Z.; Ross, M.G.; Divon, M.Y.; Hallak, M.; Beloosesky, R. Magnesium sulfate prevents maternal inflammation-induced impairment of learning ability and memory in rat offspring. Am. J. Obstet. Gynecol. 2015, 213, 851.e1-851.e8. [CrossRef]

21. Ginsberg, Y.; Khatib, N.; Weiss, B.; Arison, S.; Ross, M.G.; Weiner, Z.; Beloosesky, R. Magnesium sulfate (MG) prevents maternal inflammation induced offspring cerebral injury evident on MRI but not via IL-1beta. Neuroscience 2017, 353, 98-105. [CrossRef] [PubMed]

22. Beloosesky, R.; Khatib, N.; Ginsberg, Y.; Anabosy, S.; Shalom-Paz, E.; Dahis, M.; Ross, M.G.; Weiner, Z. Maternal magnesium sulfate fetal neuroprotective effects to the fetus: Inhibition of neuronal nitric oxide synthase and nuclear factor kappa-lightchain-enhancer of activated B cells activation in a rodent model. Am. J. Obstet. Gynecol. 2016, 215, 382.e1-382.e6. [CrossRef] [PubMed]

23. Lingam, I.; Robertson, N.J. Magnesium as a Neuroprotective Agent: A Review of Its Use in the Fetus, Term Infant with Neonatal Encephalopathy, and the Adult Stroke Patient. Dev. Neurosci. 2018, 40,1-12. [CrossRef] [PubMed]

24. Hagberg, H.; Mallard, C.; Ferriero, D.M.; Vannucci, S.J.; Levison, S.W.; Vexler, Z.S.; Gressens, P. The role of inflammation in perinatal brain injury. Nat. Rev. Neurol. 2015, 11, 192-208. [CrossRef] [PubMed]

25. Burd, I.; Breen, K.; Friedman, A.; Chai, J.; Elovitz, M.A. Magnesium sulfate reduces inflammation-associated brain injury in fetal mice. Am. J. Obstet. Gynecol. 2010, 202, 292.e1-292.e9. [CrossRef]

26. Marret, S.; Gressens, P.; Gadisseux, J.F.; Evrard, P. Prevention by magnesium of excitotoxic neuronal death in the developing brain: An animal model for clinical intervention studies. Dev. Med. Child. Neurol. 1995, 37, 473-484. [PubMed]

27. Rice, J.E., 3rd; Vannucci, R.C.; Brierley, J.B. The influence of immaturity on hypoxic-ischemic brain damage in the rat. Ann. Neurol. 1981, 9, 131-141. [CrossRef]

28. Daher, I.; Le Dieu-Lugon, B.; Lecointre, M.; Dupre, N.; Voisin, C.; Leroux, P.; Dourmap, N.; Gonzalez, B.J.; Marret, S.; LerouxNicollet, I.; et al. Time- and sex-dependent efficacy of magnesium sulfate to prevent behavioral impairments and cerebral damage in a mouse model of cerebral palsy. Neurobiol. Dis. 2018, 120, 151-164. [CrossRef] [PubMed]

29. Dupré, N.; Derambure, C.; Le Dieu-Lugon, B.; Hauchecorne, M.; Detroussel, Y.; Gonzalez, B.J.; Marret, S.; Leroux, P. HypoxiaIschemia Induced Age-Dependent Gene Transcription Effects at Two Development Stages in the Neonate Mouse Brain. Front. Mol. Neurosci. 2020, 13, 587815. [CrossRef]

30. Favrais, G.; Schwendimann, L.; Gressens, P.; Lelievre, V. Cyclooxygenase-2 mediates the sensitizing effects of systemic IL-1-beta on excitotoxic brain lesions in newborn mice. Neurobiol. Dis. 2007, 25, 496-505. [CrossRef]

31. Back, S.A.; Miller, S.P. Brain injury in premature neonates: A primary cerebral dysmaturation disorder? Ann. Neurol. 2014, 75, 469-486. [CrossRef] [PubMed]

32. Chollat, C.; Sentilhes, L.; Marret, S. Fetal Neuroprotection by Magnesium Sulfate: From Translational Research to Clinical Application. Front. Neurol. 2018, 9, 247. [CrossRef]

33. Koning, G.; Leverin, A.L.; Nair, S.; Schwendimann, L.; Ek, J.; Carlsson, Y.; Gressens, P.; Thornton, C.; Wang, X.; Mallard, C.; et al. Magnesium induces preconditioning of the neonatal brain via profound mitochondrial protection. J. Cereb. Blood Flow Metab. 2019, 39, 1038-1055. [CrossRef]

34. Dabbah-Assadi, F.; Khatib, N.; Ginsberg, Y.; Weiner, Z.; Shamir, A.; Beloosesky, R. Short-Term Effect of MgSO4 on the Expression of NRG-ErbB, Dopamine, GABA, and Glutamate Systems in the Fetal Rat Brain. J. Mol. Neurosci. 2021, 71, 446-454. [CrossRef]

35. Marret, S.; Mukendi, R.; Gadisseux, J.F.; Gressens, P.; Evrard, P. Effect of ibotenate on brain development: An excitotoxic mouse model of microgyria and posthypoxic-like lesions. J. Neuropathol. Exp. Neurol. 1995, 54, 358-370. [CrossRef] [PubMed]

36. Clancy, B.; Kersh, B.; Hyde, J.; Darlington, R.B.; Anand, K.J.; Finlay, B.L. Web-based method for translating neurodevelopment from laboratory species to humans. Neuroinformatics 2007, 5, 79-94. [CrossRef]

37. Dupré, N.; Arabo, A.; Orset, C.; Maucotel, J.; Detroussel, Y.; Hauchecorne, M.; Gonzalez, B.J.; Marret, S.; Vivien, D.; Leroux, P. Neonatal cerebral hypoxia-ischemia in mice triggers age-dependent vascular effects and disabilities in adults; implication of tissue plasminogen activator (tPA). Exp. Neurol. 2020, 323, 113087. [CrossRef]

38. Marret, S.; Foix-L'helias, L.; Ancel, P.Y.; Kaminski, M.; Larroque, B.; Marcou-Labarre, A.; Laudenbach, V. Is it possible to protect the preterm infant brain and to decrease later neurodeveloppemental disabilities? Arch. Pediatr. 2008, 15 (Suppl. 1), S31-S41. [CrossRef]

39. Gathwala, G.; Khera, A.; Singh, J.; Balhara, B. Magnesium for neuroprotection in birth asphyxia. J. Pediatr. Neurosci. 2010, 5, 102-104. [CrossRef]

40. Borja-Del-Rosario, P.; Basu, S.K.; Haberman, S.; Bhutada, A.; Rastogi, S. Neonatal serum magnesium concentrations are determined by total maternal dose of magnesium sulfate administered for neuroprotection. J. Perinat. Med. 2014, 42, $207-211$. [CrossRef]

41. Jauch, R.; Cho, M.K.; Jakel, S.; Netter, C.; Schreiter, K.; Aicher, B.; Zweckstetter, M.; Jackle, H.; Wahl, M.C. Mitogen-activated protein kinases interacting kinases are autoinhibited by a reprogrammed activation segment. EMBO J. 2006, 25, 4020-4032. [CrossRef] [PubMed] 
42. Crowther, C.A.; Middleton, P.F.; Voysey, M.; Askie, L.; Zhang, S.; Martlow, T.K.; Aghajafari, F.; Asztalos, E.V.; Brocklehurst, P.; Dutta, S.; et al. Effects of repeat prenatal corticosteroids given to women at risk of preterm birth: An individual participant data meta-analysis. PLoS Med. 2019, 16, e1002771. [CrossRef] [PubMed]

43. Ikonomidou, C.; Bosch, F.; Miksa, M.; Bittigau, P.; Vockler, J.; Dikranian, K.; Tenkova, T.I.; Stefovska, V.; Turski, L.; Olney, J.W. Blockade of NMDA receptors and apoptotic neurodegeneration in the developing brain. Science 1999, 283, 70-74. [CrossRef]

44. Lecointre, M.; Vezier, C.; Benard, M.; Ramdani, Y.; Dupre, N.; Brasse-Lagnel, C.; Henry, V.J.; Roy, V.; Marret, S.; Gonzalez, B.J.; et al. Age-dependent alterations of the NMDA receptor developmental profile and adult behavior in postnatally ketamine-treated mice. Dev. Neurobiol. 2015, 75, 315-333. [CrossRef] [PubMed]

45. Raikkonen, K.; Gissler, M.; Kajantie, E. Associations Between Maternal Antenatal Corticosteroid Treatment and Mental and Behavioral Disorders in Children. JAMA 2020, 323, 1924-1933. [CrossRef]

46. Loepke, A.W. Developmental neurotoxicity of sedatives and anesthetics: A concern for neonatal and pediatric critical care medicine? Pediatr. Crit. Care Med. 2010, 11, 217-226. [CrossRef]

47. Poppe, T.; Thompson, B.; Boardman, J.P.; Bastin, M.E.; Alsweiler, J.; Deib, G.; Harding, J.E.; Crowther, C.A.; Mag, N.U.M.S.G Effect of antenatal magnesium sulphate on MRI biomarkers of white matter development at term equivalent age: The magnum study. EBioMedicine 2020, 59, 102957. [CrossRef]

48. Chollat, C.; Enser, M.; Houivet, E.; Provost, D.; Benichou, J.; Marpeau, L.; Marret, S. School-age outcomes following a randomized controlled trial of magnesium sulfate for neuroprotection of preterm infants. J. Pediatr. 2014, 165, 398-400.e3. [CrossRef]

49. Singhi, S.; Johnston, M. Recent advances in perinatal neuroprotection. F1000Research 2019. [CrossRef]

50. Nowak, L.; Bregestovski, P.; Ascher, P.; Herbet, A.; Prochiantz, A. Magnesium gates glutamate-activated channels in mouse central neurones. Nature 1984, 307, 462-465. [CrossRef]

51. Hardingham, G.E.; Do, K.Q. Linking early-life NMDAR hypofunction and oxidative stress in schizophrenia pathogenesis. Nat. Rev. Neurosci. 2016, 17, 125-134. [CrossRef] [PubMed]

52. Clerc, P.; Young, C.A.; Bordt, E.A.; Grigore, A.M.; Fiskum, G.; Polster, B.M. Magnesium sulfate protects against the bioenergetic consequences of chronic glutamate receptor stimulation. PLoS ONE 2013, 8, e79982. [CrossRef] [PubMed]

53. Jantzie, L.L.; Talos, D.M.; Jackson, M.C.; Park, H.K.; Graham, D.A.; Lechpammer, M.; Folkerth, R.D.; Volpe, J.J.; Jensen, F.E. Developmental expression of N-methyl-D-aspartate (NMDA) receptor subunits in human white and gray matter: Potential mechanism of increased vulnerability in the immature brain. Cereb. Cortex 2015, 25, 482-495. [CrossRef] [PubMed]

54. Kang, S.W.; Choi, S.K.; Park, E.; Chae, S.J.; Choi, S.; Joo, H.J.; Lee, G.J.; Park, H.K. Neuroprotective effects of magnesium-sulfate on ischemic injury mediated by modulating the release of glutamate and reduced of hyperreperfusion. Brain Res. 2011, 1371, 121-128. [CrossRef] [PubMed]

55. Hansen, K.B.; Yi, F.; Perszyk, R.E.; Furukawa, H.; Wollmuth, L.P.; Gibb, A.J.; Traynelis, S.F. Structure, function, and allosteric modulation of NMDA receptors. J. Gen. Physiol. 2018, 150, 1081-1105. [CrossRef]

56. Leroux, P.; Omouendze, P.L.; Roy, V.; Dourmap, N.; Gonzalez, B.J.; Brasse-Lagnel, C.; Carmeliet, P.; Leroux-Nicollet, I.; Marret, S. Age-dependent neonatal intracerebral hemorrhage in plasminogen activator inhibitor 1 knockout mice. J. Neuropathol. Exp. Neurol. 2014, 73, 387-402. [CrossRef]

57. Ballabh, P. Intraventricular hemorrhage in premature infants: Mechanism of disease. Pediatr. Res. 2010, 67, 1-8. [CrossRef]

58. Chollat, C.; Le Doussal, L.; De La Villeon, G.; Provost, D.; Marret, S. Antenatal magnesium sulphate administration for fetal neuroprotection: A French national survey. BMC Pregnancy Childbirth 2017, 17, 304. [CrossRef]

59. Boardman, J.P.; Ireland, G.; Sullivan, G.; Pataky, R.; Fleiss, B.; Gressens, P.; Miron, V. The Cerebrospinal Fluid Inflammatory Response to Preterm Birth. Front. Physiol. 2018, 9, 1299. [CrossRef]

60. Quarta, A.; Berneman, Z.; Ponsaerts, P. Neuroprotective modulation of microglia effector functions following priming with interleukin 4 and 13: Current limitations in understanding their mode-of-action. Brain Behav. Immun. 2020, 88, 856-866. [CrossRef]

61. Chhor, V.; Le Charpentier, T.; Lebon, S.; Ore, M.V.; Celador, I.L.; Josserand, J.; Degos, V.; Jacotot, E.; Hagberg, H.; Savman, K.; et al. Characterization of phenotype markers and neuronotoxic potential of polarised primary microglia In Vitro. Brain Behav. Immun. 2013, 32, 70-85. [CrossRef] [PubMed]

62. Li, B.; Cao, H.; Zhao, Y.; Cheng, M.; Qin, H.; Cheng, T.; Hu, Y.; Zhang, X.; Liu, X. In Vitro and in Vivo responses of macrophages to magnesium-doped titanium. Sci. Rep. 2017, 7, 42707. [CrossRef] [PubMed]

63. Hardy, S.; Kostantin, E.; Wang, S.J.; Hristova, T.; Galicia-Vazquez, G.; Baranov, P.V.; Pelletier, J.; Tremblay, M.L. Magnesiumsensitive upstream ORF controls PRL phosphatase expression to mediate energy metabolism. Proc. Natl. Acad. Sci. USA 2019, 116, 2925-2934. [CrossRef]

64. Porte, B.; Hardouin, J.; Zerdoumi, Y.; Derambure, C.; Hauchecorne, M.; Dupre, N.; Obry, A.; Lequerre, T.; Bekri, S.; Gonzalez, B.; et al. Major remodeling of brain microvessels during neonatal period in the mouse: A proteomic and transcriptomic study. J. Cereb. Blood Flow Metab. 2017, 37, 495-513. [CrossRef]

65. Huang, D.W.; Sherman, B.T.; Lempicki, R.A. Systematic and integrative analysis of large gene lists using DAVID bioinformatics resources. Nat. Protoc. 2009, 4, 44-57. [CrossRef] [PubMed]

66. Huang, D.W.; Sherman, B.T.; Lempicki, R.A. Bioinformatics enrichment tools: Paths toward the comprehensive functional analysis of large gene lists. Nucleic Acids Res. 2009, 37, 1-13. [CrossRef] [PubMed] 
67. Hosack, D.A.; Dennis, G., Jr.; Sherman, B.T.; Lane, H.C.; Lempicki, R.A. Identifying biological themes within lists of genes with EASE. Genome Biol. 2003, 4, R70. [CrossRef] [PubMed]

68. Supek, F.; Bosnjak, M.; Skunca, N.; Smuc, T. REVIGO summarizes and visualizes long lists of gene ontology terms. PLoS ONE 2011, 6, e21800. [CrossRef]

69. Furuie, H.; Yamada, K.; Ichitani, Y. MK-801-induced and scopolamine-induced hyperactivity in rats neonatally treated chronically with MK-801. Behav. Pharmacol. 2013, 24, 678-683. [CrossRef] 